\title{
ضبط الأدلة فى الجرائم الإلكترونية \\ بين الإجراءات التقليدية والإجراءات الحديثة
}

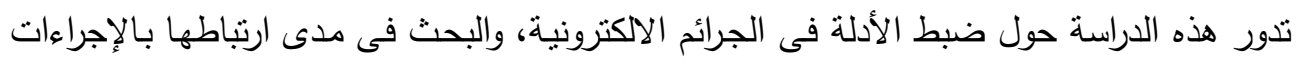

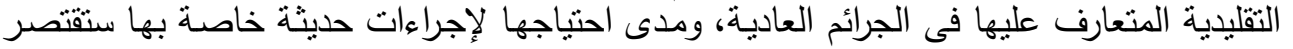

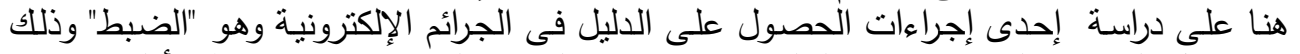

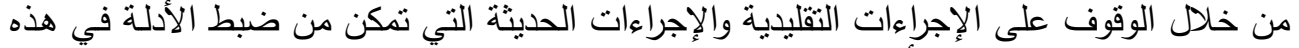

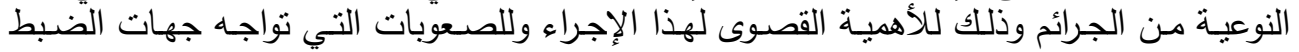

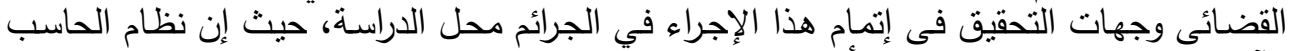

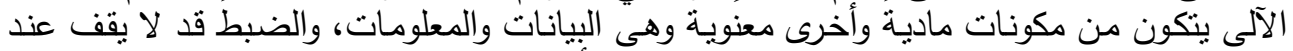

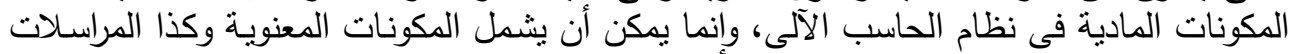
الإلكترونية التى تتم عبر هذه الوسائل.

هقدهة

منذ العقد الأخير من القرن العشرين أصبح للجرائم الإكترونية تأثثرات غاية فى السوء على الحياة العامة، وتحملت جميع الدول خسائر فادحة تصل إلى مليارات الدولارات وتتضاعف هذه الخسائر بمرور السنوات، رغم الجهود المبذولة لمكافحة هذه النوعية من الجرائم، وخاصة عقب ظهور الأدلة الإلكترونية وما صاحبه من مشكلات عديدة،

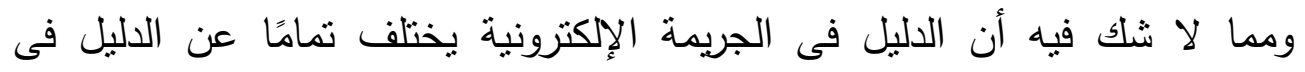
الجريمة التقليدية، وذللك من حيث كم البيانات المخزنة فى جهاز الحاسب وكيفية إثباتها، سواء من حيث وسيلة الإثبات أو القائم بالإثبات، وما إن كانت ثتوافر لديه

* مدرس القانون الجنائى، المركز القومى للبحوث الاجتماعية والجنائية . المجلة الجنائية القومية، المجلد الواحد والستون، العدد الثالث، نوفمبر 11 . . . . 
خبرة كافية فى هذا المجال من عدمه، ولذلك فالصعوبات التى تعترض إثبات وتحصيل الدليل الجنائى فى الجريمة الإلكترونية كثيرة ومنتوعة، منها ما يتعلق بالدليل

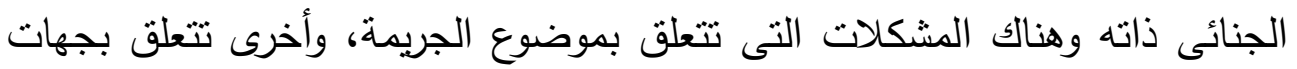

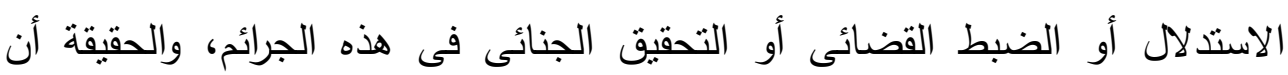
أسلوب الحصول على الدليل الإكترونى فى هذه الجرائم محكوم بضابطين الأول: يتعلق بضرورة وجود قاعدة قانونية تقرر الإجراء القانونى الواجب إتباعه فى مثل هذه

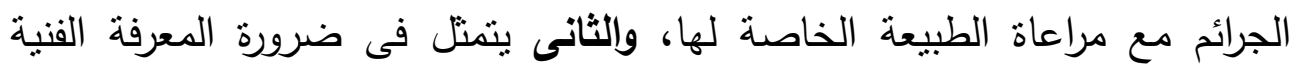

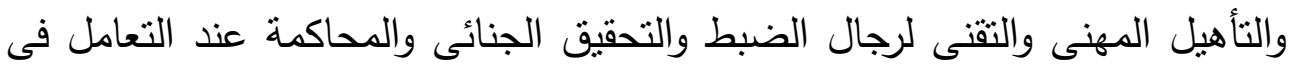

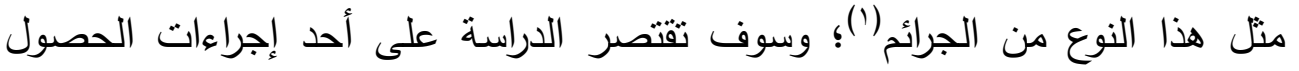

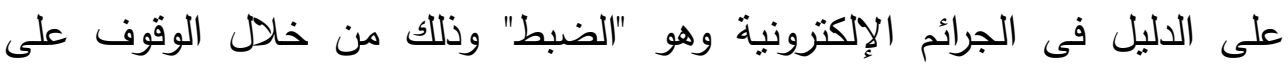

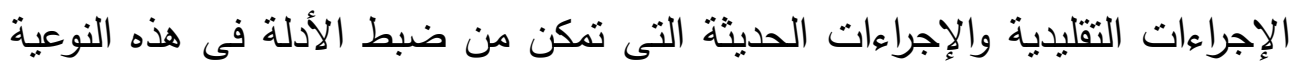

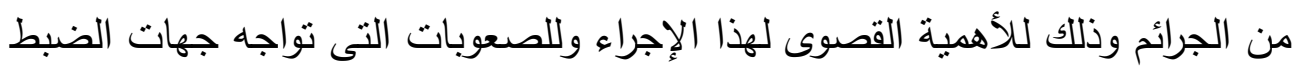
القضائى وجهات التحقيق فى إتمام هذا الإجراء فى الجرائم محل الدراسة، حيث إن الن الن النهاء نظام الحاسب الآلى يتكون من مكونات مادية وأخرى معنوية وهى البئ البيانات

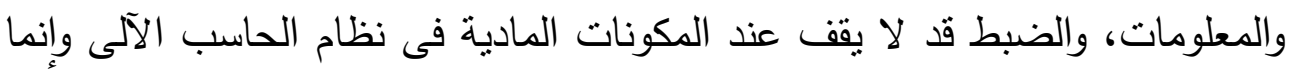

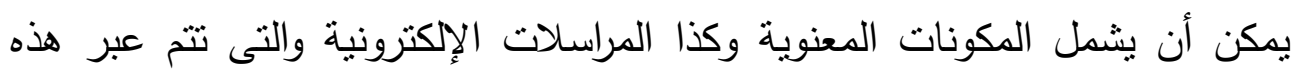
الوسائل، وحيث أن ضبط المكونات المادية لا يثير إثكالية قانونية وإنما الإثكالية

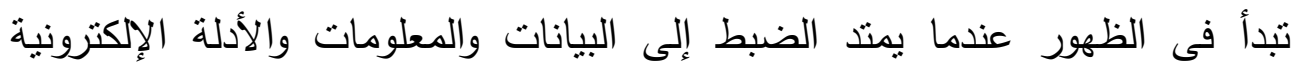
لتحديد مدى إمكانية ذلك. وكذلك إبراز أوجه الاختلاف فى إجراءات الضبط حال ارتكاب الجريمة الإكترونية من خلا شبكة الإنترنت. والتى استفاضت فيها اتفاقية

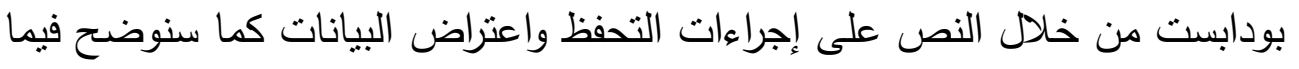


بعد، وتتمثل الصعوبة فى هذه الحالات من الناحية التشريعية لعدم وجود نصوص خاصة بذلك فى العديد من التشريعات وخاصة العربية وعلى رأسها التشريع المصرى. وتختلف طبيعة الضبط فى نطاق الجرائم الإلكترونية، فالضبط فى الجرائم الإلكترونية بنطوى على حالات مختلفة دن حيث ظروفها وأحوالها، فهى تتطلب لإجراء الضبط بها تقنيات خاصة تغاير حالات ضبط الأدلة التقليدية. وسوف نتتاول إجراءات الضبط من خلاءل ما يلى:

\section{أولاً: الإجراءات التقايدية لضبط الجرائم الإلكتزونية}

تتص المادة (00) من قانون الإجراءات الجنائية رقم ،10 لسنة . 190 "لمأمورى الضبط القضائى أن يضبطوا الأوراق والأسلحة وكل ما يحتمل أن يكون قد استعمل فى ارتكاب الجريمة أو نتج عن ارتكابها أو ما وقعت عليه الجريمة وكل ما يفيد فى كثف الحقيقة".

وتعرض هذه الأثياء على المتهم، ويطلب منه إبداء ملاحظاته عليها، ويعمل بذلك محضر يوقع عليه من المتهم، أو يذكر فيه امتتاعه عن التوقيع. يعرف البعض الضبط فى البيئة الإلكترونية بأنه "وضع اليد على الدعائم المادية المخزن فيها البيانات الإكترونية أو المعلومات التى تتصل بجريمة من الجرائم الإلكترونية وقعت، وتُقيد فى كثف الحقيقة عنها وعن مرتكبهاب(ان. ولم يتطرق قانون الإجراءات الجنائية المصرى إلى قواعد الضبط فى الجرائم الإككترونية، مكتقيًا بالقواعد العامة للضبط فى الجرائم، وقد تتاولت الاتفاقية الأوروبية (بودابست) أحكام الضبط فى الجرائم الإلكترونية من خلال المادة (9 (1) فاستخدمت المصطلح التقليدى لهذا الإجراء (الضبط)، وأضافت إلى جانب ذلك عبارة الحصول بأية طريقة مماثلة على البيانات المعلوماتية للإثشارة إلى أساليب أخرى مستحدثة 
للضبط، فصطلح الضبط يمكن أن يشمل المكونات المادية التى يمكن تخزين البيانات والمعلومات عليها، كما يشمل طرق الوصول أو التحفظ على نسخة من تلكئل

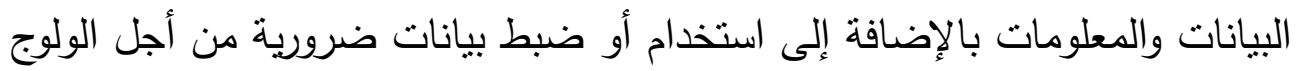

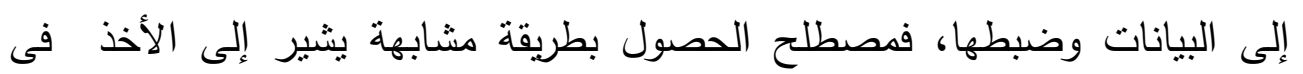

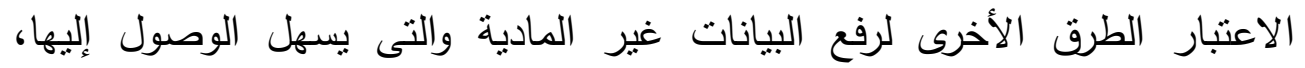

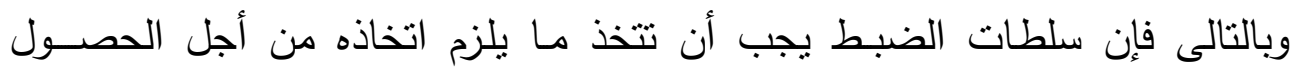
علىى البيانات والمحافظة على سلامتها، فيجب أن تكون تلان البيانات متحفظًا عليها فى الحالة التى تـم العثور عليها فيها لحظة الضبط، وعدم تغيريها من خلال تزميزها عن طريق أى وسيلة(r).

والضبط بطبيعته وبحسب تتظيمه القانونى وغايته لا يرد إلا على الأثنياء التى لتى

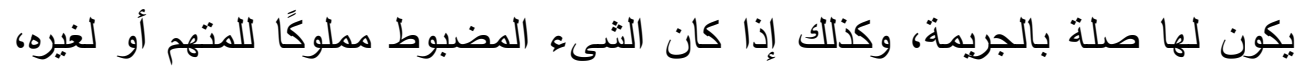

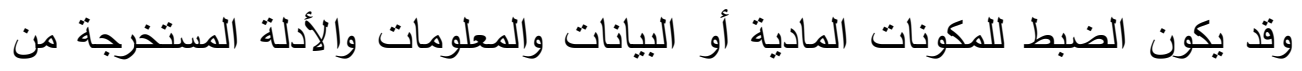
الحاسب. وبالتالى الضبط فى الجرائم الالكترونية قد يرد على المكونات المادية أو الو المعنوية أو كليهما.

\section{ا - ضبط المكونات المادية فى نظام الحاسب الآلى}

بالنسبة للمكونات المادية للحاسب الآلى فلا يثير ضبطها أى مشكلات، فيمكن ضبط الماليط وحدات الحاسب الآلى الآتية: وحدة المدخلات بما تثمله من مفردات كلوحة المفاتيح

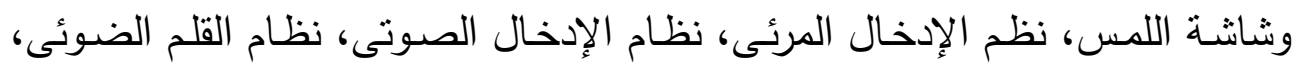

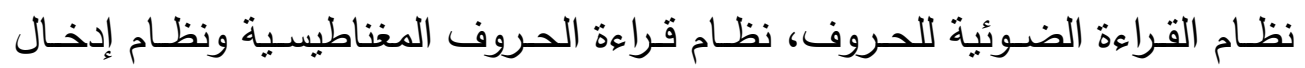

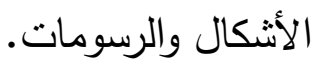


ويمكن أيضًا ضبط وحدة الذاكرة الرئيسة سواًء كانت ذاكرة للقراءة فقط أم كانت

للقراءة والكتابة معًا، وضبط وحدة الحساب والمنطق بما تشعله من دائرة إلكترونية

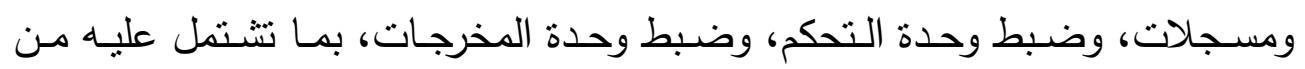

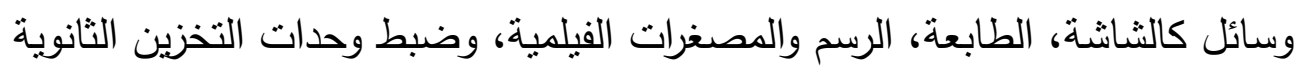

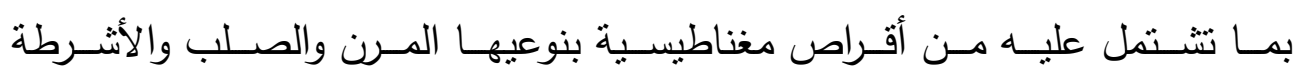

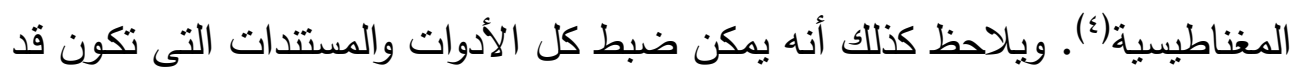

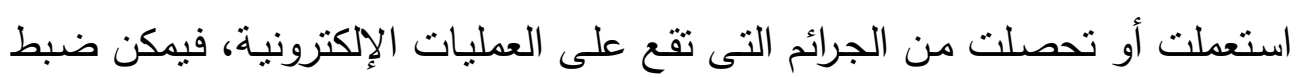

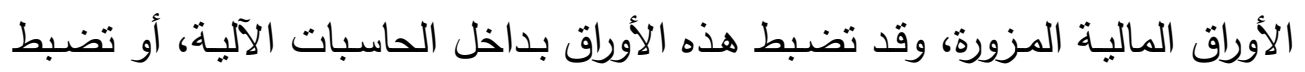

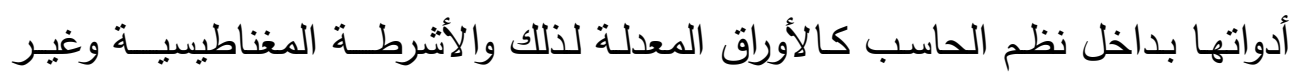

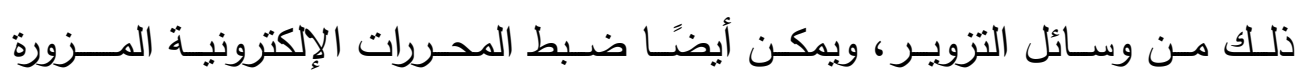

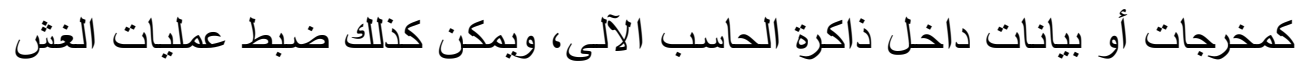

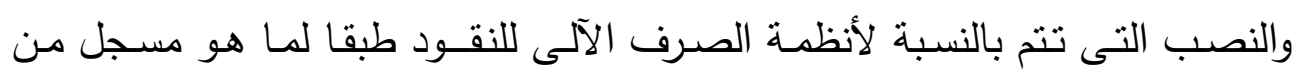

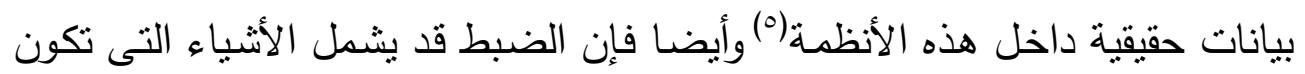
قد تعرضت للتخزين أو للإتـلاف على النحو الذى تكثـف عنه الكيانـات الماديـة والمنطقية للحاسبات الآلية.

\section{r- باط المكونات المعنوية للحاسب الآلى}

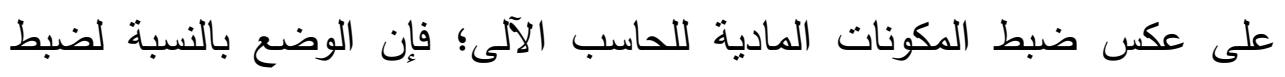

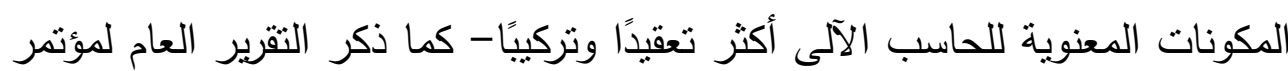
(7)A.I.D 
فإذا كان الضبط يتم لمكونات الحاسب المادية كمحتوى للييانات، فهل الثىء الذى يتم ضبطه هو هذا الثىى المادى؟ أم أنه يتضمن كذلك البيانات غير المادية؟ وما السند القانونى القائم عليه الضبط؟ هلئ

\section{وتعددت الآراء فى هذا الثأن وتثعبت فى اتجاهات مختلفة}

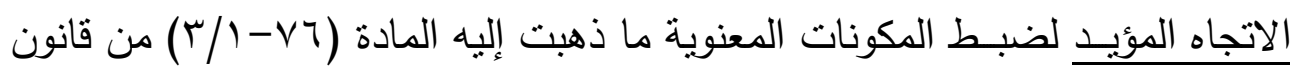

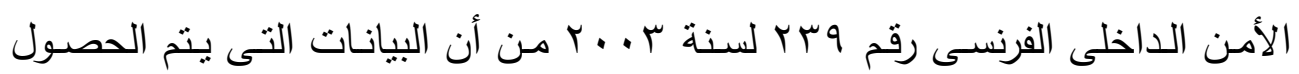
عليها من تفتيش نظام الحاسب الآلى يتعين نسخها على دعامات، ثم يتم تحريز هذه

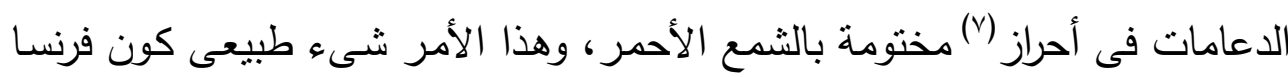

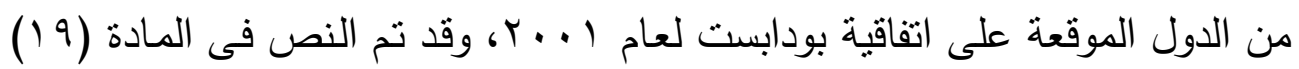

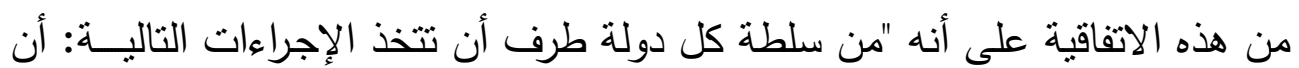

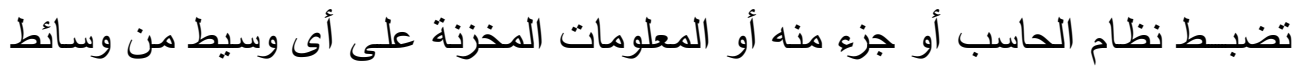

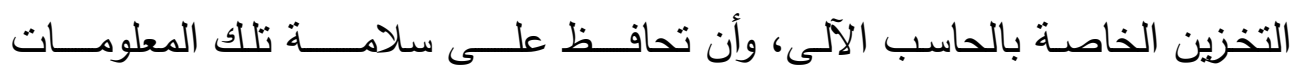
المخزنة ومن التطبيقـات التشريعية التى تجيز ضبط مكونات المعلوماتية من خلال

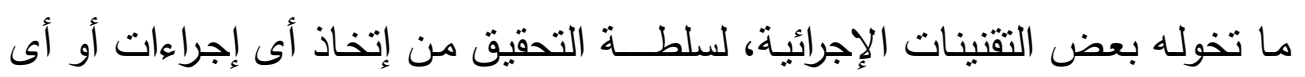

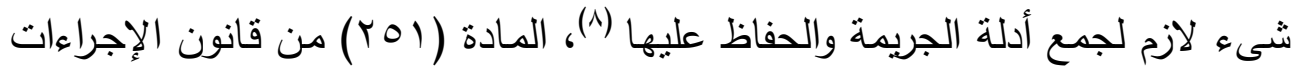

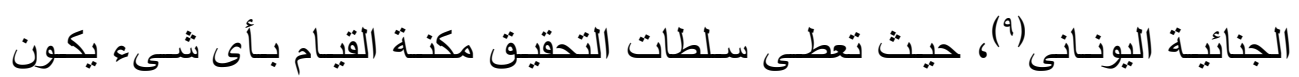
ضروريا لجمع وحماية الدليل.

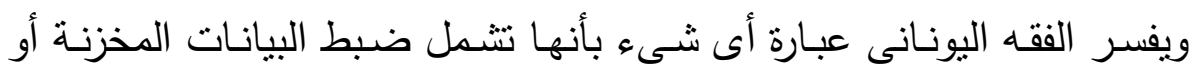

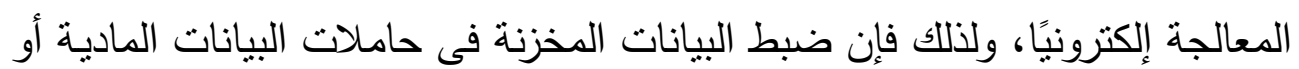
فى الذاكرة الداخلية لا تسبب أية مشكلة فى اليونان، إذ بمقدور المحقق أن يعطى أمرًا

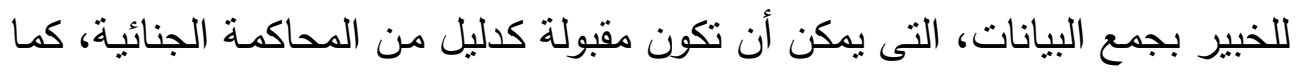


تجيز المادة (• צr) من قانون الإجراءات الجنائية اليونانى استخدام القوة العسكرية فى

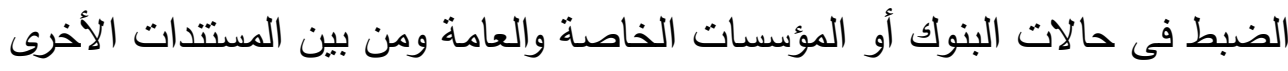

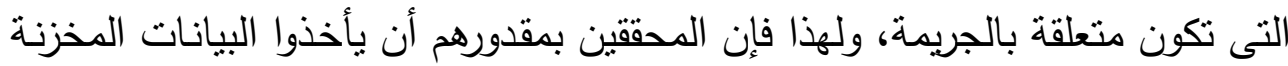

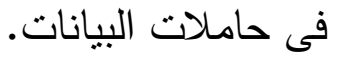

ولكن قد تثور المشكلة فى الحالات التى تكون فيها البيانات مخزنة فى وحدات معالجة مركزية فى حاسب ضمن شبكة معلومات كبيرة، ففى هذه الحالة فإن صياغة شـرط يعطى للمحقق إمكانيـة ضبط هذا النظـام الثبكى بأكملـه وعزلـه عن البيئة

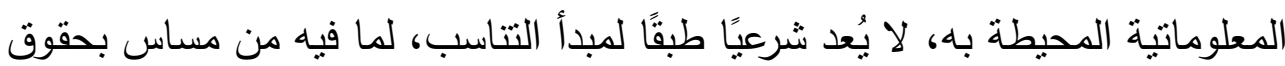
الغير فى النظام محل الضبط. وفى كندا نجد الوضـع التشـريعى نفسـه فالمـادة (INV) مـن القانون الجنائى

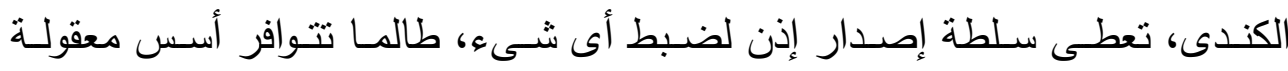

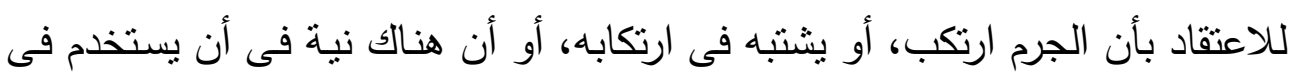

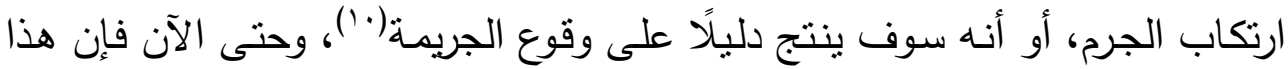
النص يُفسر بوضوح تام على أنه يسمح بضبط بيانات الحاسب غير المحسوسة.

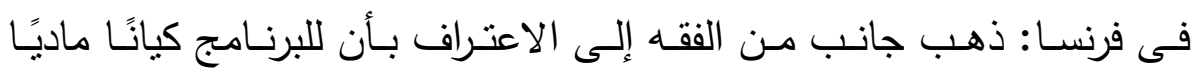

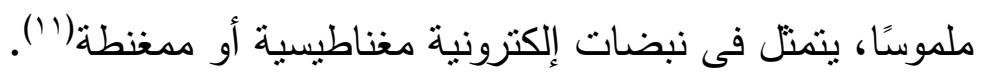
ولذلك نجد أن قضاء محكمة النقض الفرنسية وقبل تجريم المشرع لسرقة الطاقة بموجب نص المادة الآ/ من قانون العقوبات الفرنسى، ذهب إلى صلاحية التيار

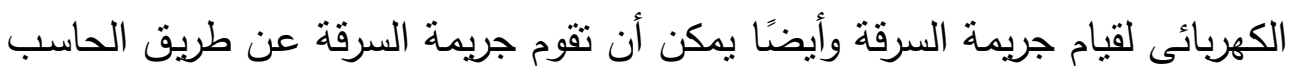

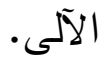




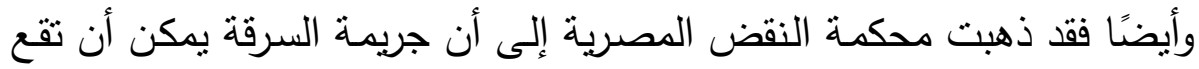

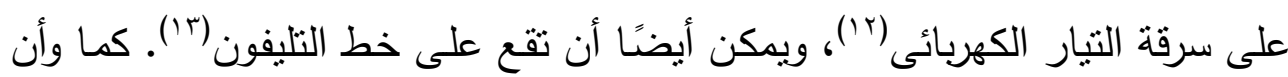

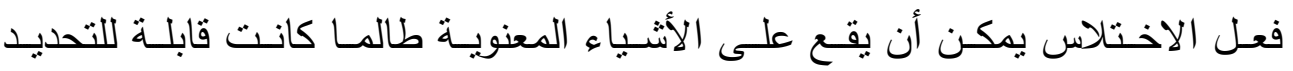

كالمعلومات التى تحتويها دعامات مادية كالكتابة وشرائط التسجيل المغناطيسية.

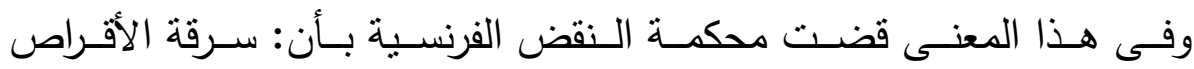
الدغناطيسية "الديسكات" تتضمن فى الوقت ذاته سرقة محتوياتها المعلوماتيـة للفترة

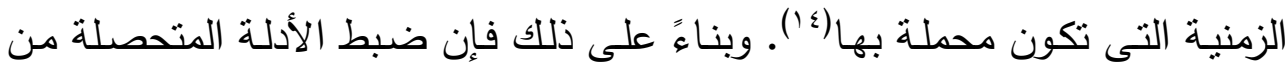
الجرائم الإلكترونيـة يمكن أن يقع على الكيانـات المعنويـة فـى الوسـائل الإكترونيـة،

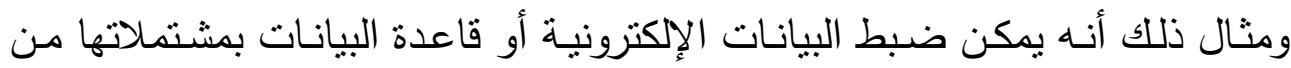
ملفات وسجلات وحقول وسواء أتخذت شكل برامج نظام أو برامج نطبيقات (10).

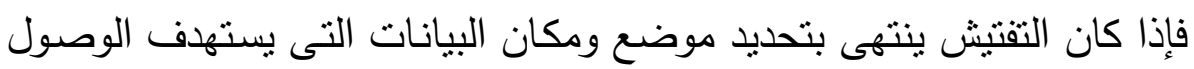

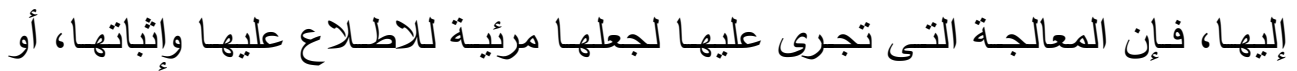

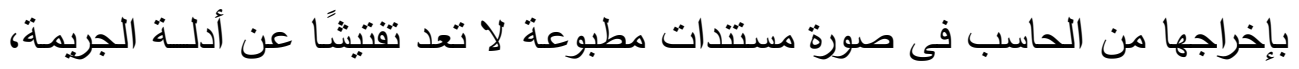

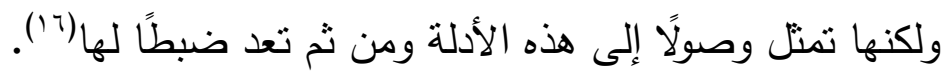

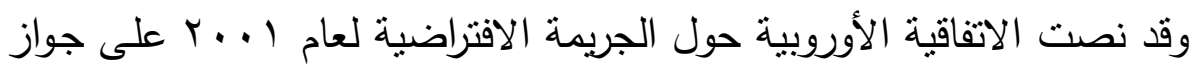

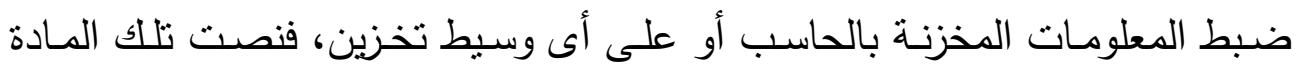

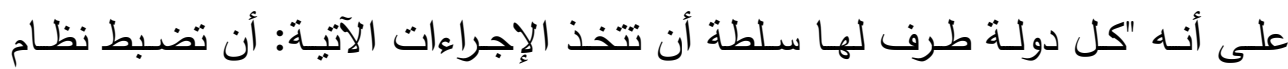

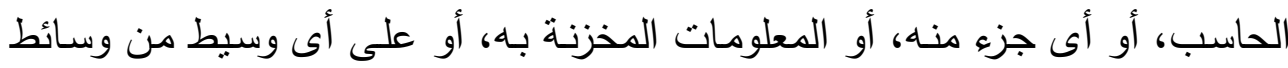

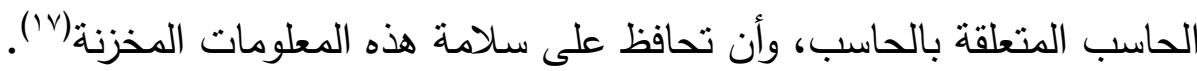

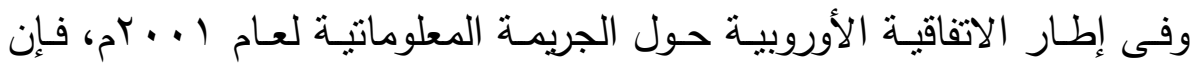

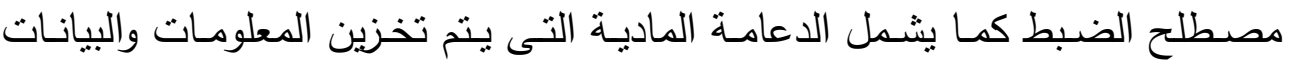


عليها أو الوصول أو التحفظ على نسخة منها، يشمل أيضًا استخدام أو ضبط البرامج الفورية اللازمة للولوج إلى هذه البيانات وضبطها، ومن ثم فقد تم استخدام مصطلح

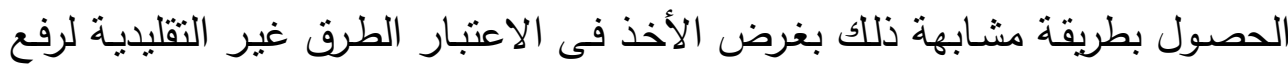

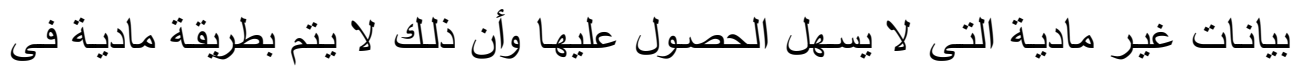

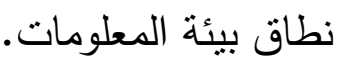

وتجدر الإثارة إلى أن ضبط الأدلة المتحصلة من الحاسبات الآلية قد تكتنفه

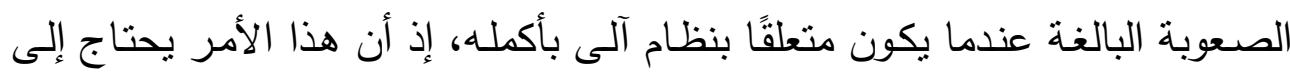

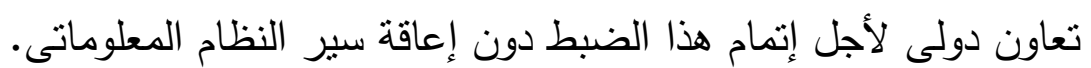

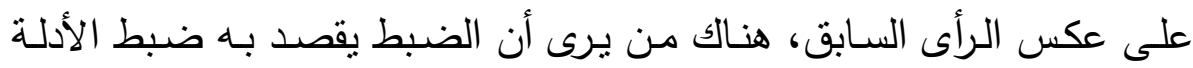
المادية التى تُقيد فى كثف الحقيقة فإن هذا الدفهوم المادى لا ينطبق على بيانات

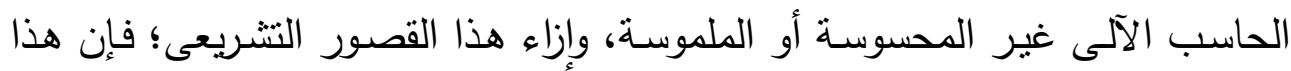

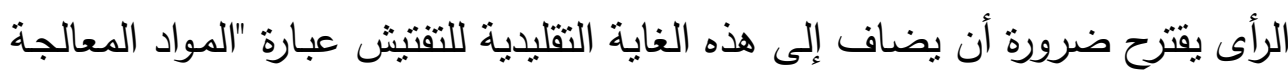
عن طريق الحاسب الآلى أو بيانات الحاسب الآلى"، وبذللك تصبح الغايـة الجديدة

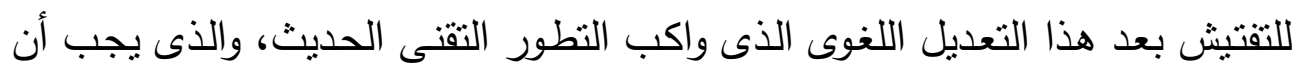

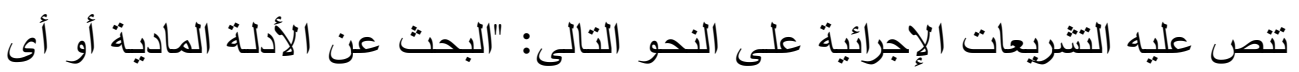

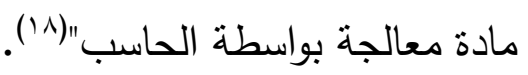
فى فرنسا: يرى بعض الفقهاء أن النبضات الإلكترونية أو الإشـارات الإلكترونية

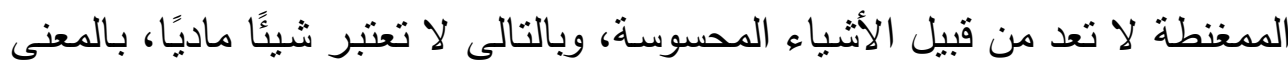
المألوف للكلمة(19)، ولذا لا بمكن ضبطنه.

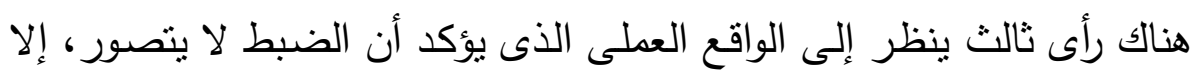
إذا أتخذت البيانات صورة مادية. 
فى ألمانيا: الأدلة المضبوطة يجب أن تكون أنشياء ملموسـة (القسم ؟ 9 من قانون الإجراءات الجنائية)، وذلك يشمل ليس فقط نظم الحاسب الآلى، بل أيضًا

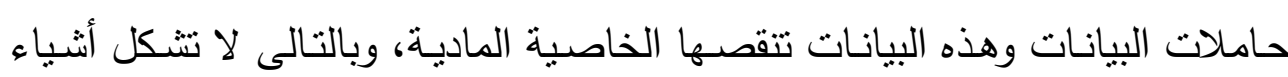
يمكن ضبطها. وذهـب رأى فقهى فـى ألمانيـا إلى أن الأثــياء المحسوسـة هـى التـى يمكن

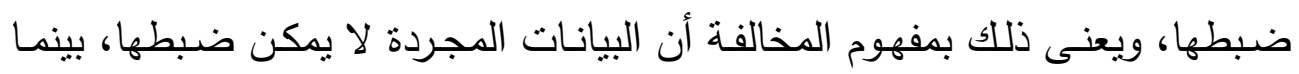

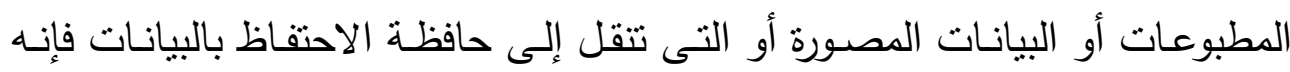

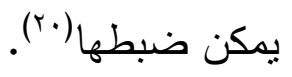
ونرى أنه يجب ألا نقف من تفسير لفظ شىء على المعنى الحرفى للكلمة، إذ

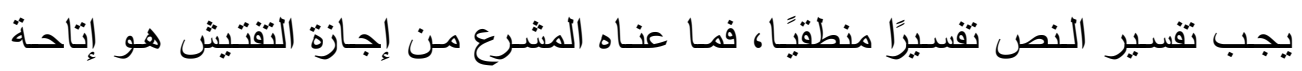

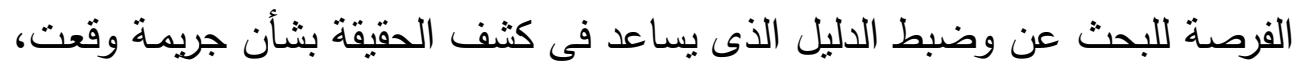
وهذه الغاية تكون متوافرة بصرف النظر عن طبيعة الوسط المراد تفتيشه أو الأشياء

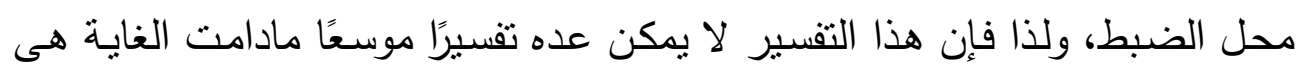

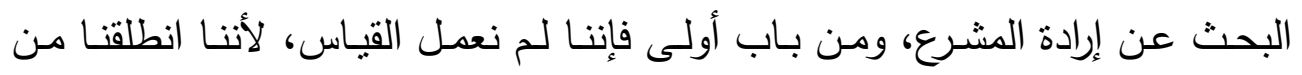

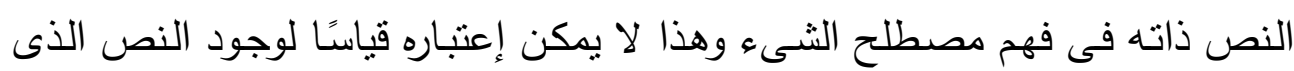
نعتقد أنه يستوعب المسألة موضوع البحث. فالثـىء إذا كان يمثل قيمة إقتصـادية أو ذهنية فإنـه يستحق الحمايـة الجنائية

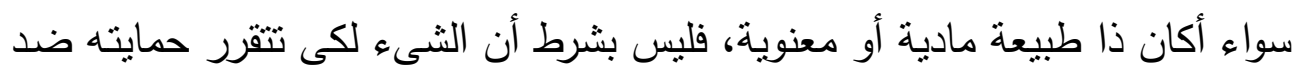

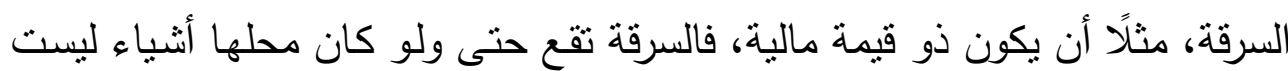

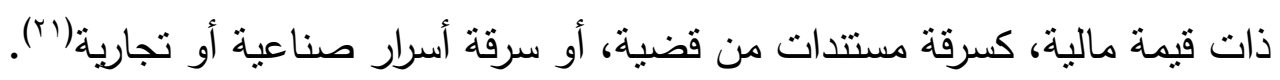


إلا أن الإنشكالية الأهم بشـأن الضبط تظهر حينهـا يتعبن ضبط المعطبات

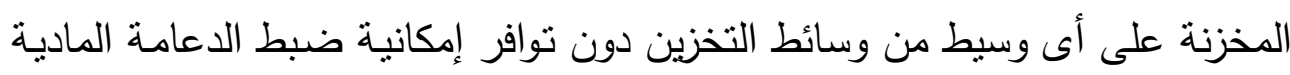
المخزن عليها هذه المعطيات، كذللك لبس بالإمكان ضبط النظام كله أو الثبكات

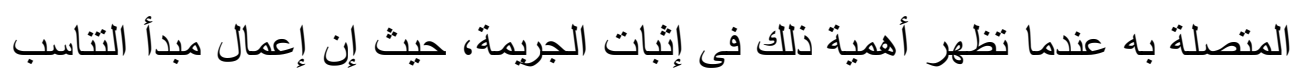

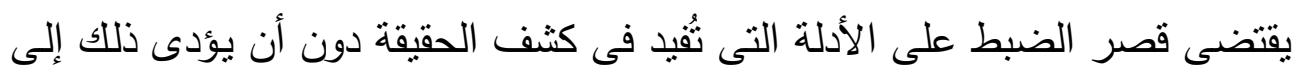

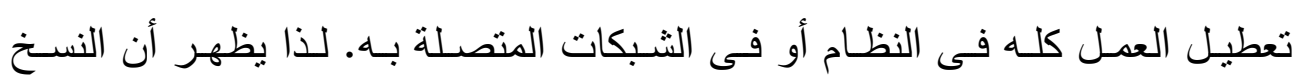
الأسلوب الأمنل الذى يمكن استخدامه فى ضبط المعطيات الإلكترونية.

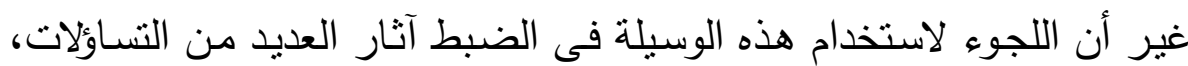
سواء من ناحية مشروعيته أو حجية الدليل المستمد منه. ومن الطبيعى أن تختلف طريقة ضبط الأشياء المادية، كضبط جهاز الحاسب التباء

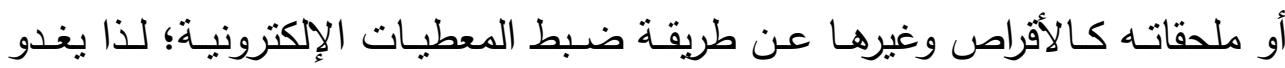

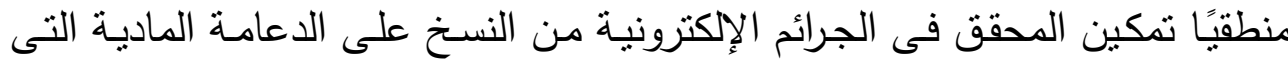

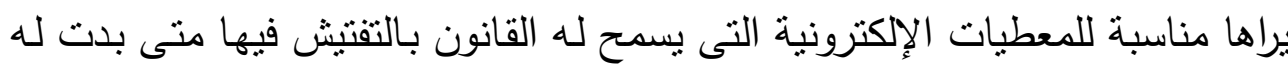
أهميتها فى كثف الحقيقة. ويتمثل إختلاف طريقة الضبط فى "الجرائم الإلكترونية" من خـال النسخخ عن الضبط النقليدى فى بقاء الثـىء المضبوط تحت يد حـائز المعطيات الإكترونيـة المضبوطة، بينما "الضبط المادى" يخرج الثىء المضبوط من السبطرة المادية لحائزه،

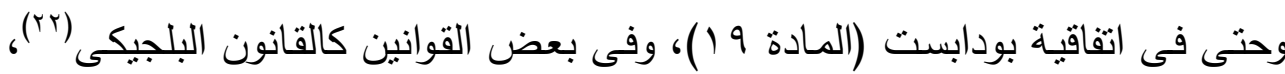

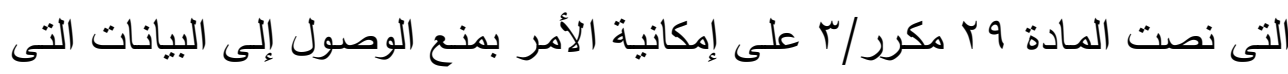

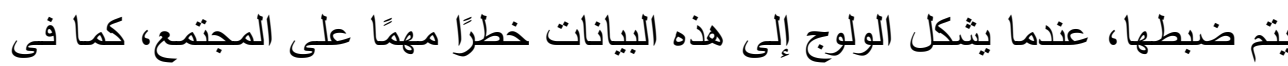

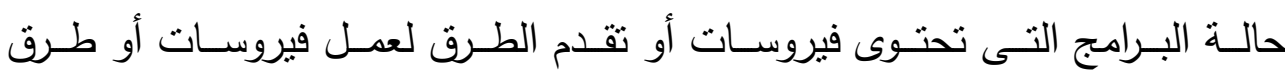


القرصنة... التخ، فإن هذه البيانات نستمر فى الوجود، وكل ما فى الأمر أن يمنع المشتبه به من الولوج إليها.

والعديد من التتريعات تعتبر قواعد الضبط التقليدى صالحة للتطبيق فى مجال الجرائم الإلكترونيـة. ولهذا السبب لم تشرع معظم الدول نظمًا تخنص بالضبط فى

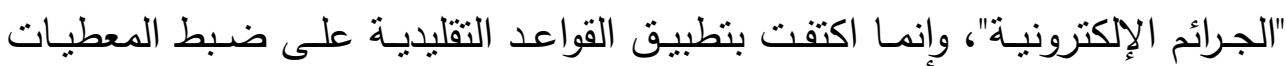

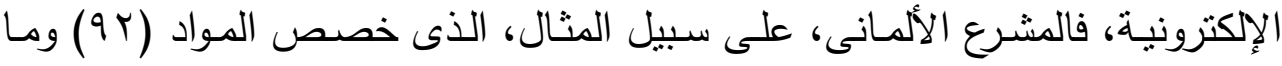

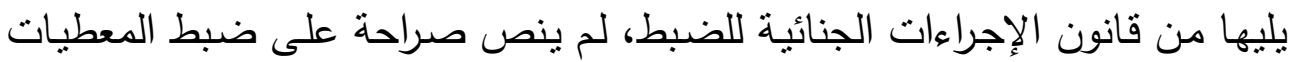

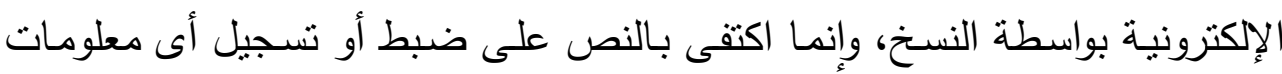
تظهر مفيدة لكثف الحقيقة. ويظل التسـاؤل قائمًا بشـأن إمكانيـة استخدام المعطيات التى تم ضبطها من

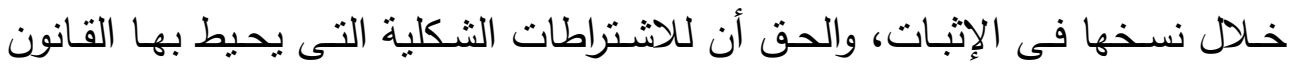

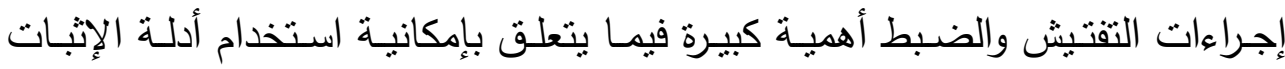
المتحصل عليها من خلال هذه الإجراءات، وقد تتير هذه الثروط الثكلية صعوبات خاصة عندما يراد تطبيقها على التفتيش عن المعلومات الإلكترونية وضبطها، ولاشك أن أسلوب النسخ ينتج عنه دليل إلكترونى، وفى مجال ضبط المعطيات الإكترونية، وفى ظل غياب انتراط إجراءات خاصـة تضمن صدق المعطيات المضبوطة، ييقى

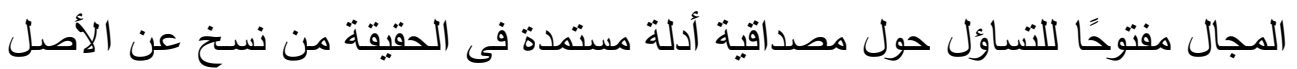
المخزن فى الوسط الإلكترونى.

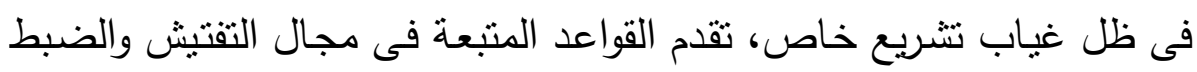
التقليدى تصورًا لما يتعين إتباعه من أجل المحافظة على الداليل الإكترونى. 
ويالإمكان إجمال ذلك فى احتياطيين رئيسين يتعين مراعاتهما:

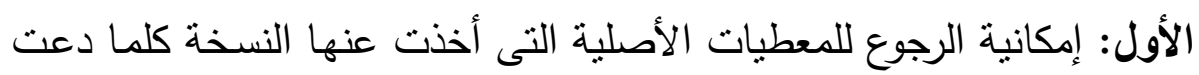

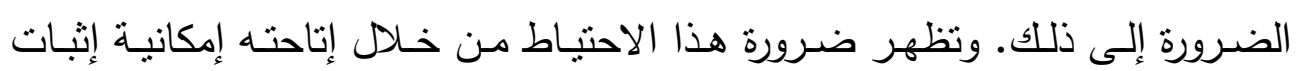
مطابقة النسخ المضبوط عليها المعطيات الإكترونية للأصل.

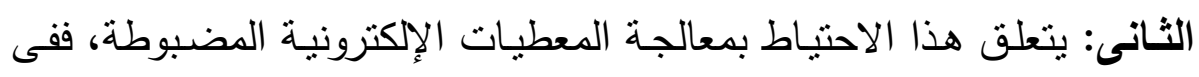

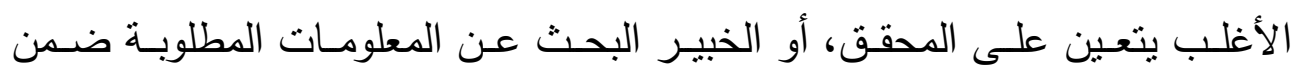

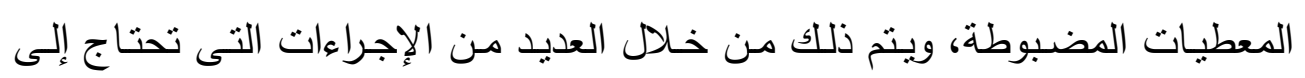

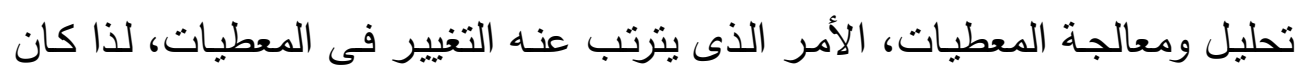

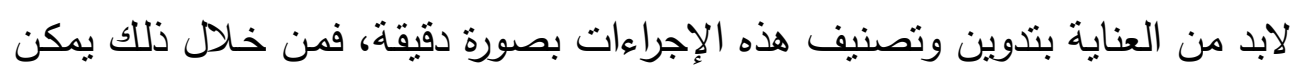

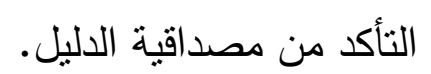
ولتحقيق الضمانات السـابقة يتعين على المحقق المكلف بالتحقيق فى الدليل

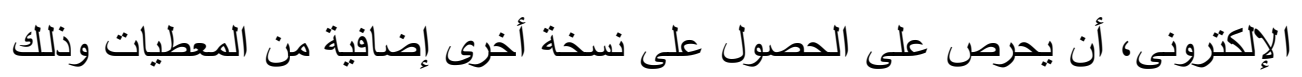
للعمل بها كدليل على إجراءات المعالجة التى وقعت على المعتى المعيات الإلكترونية.

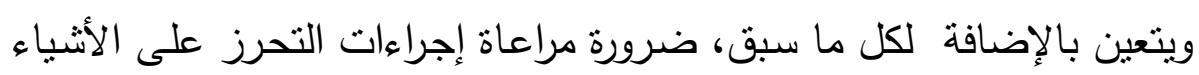

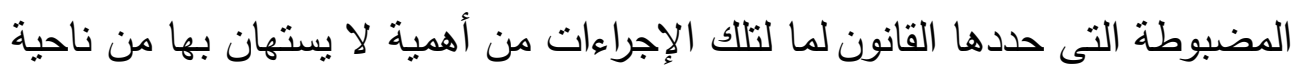
التمكين من استخدام المعطيات الإكترونية المضبوطة فى الإثبات(rr).

\section{ثانياً: الإجراءات الحديثة لضبط الأدلة الإلكتزونية}

تتم هذه الإجراءات من خلال التحفظ على الأدلة الإلكترونية أو اعتراضها ومراقبتها

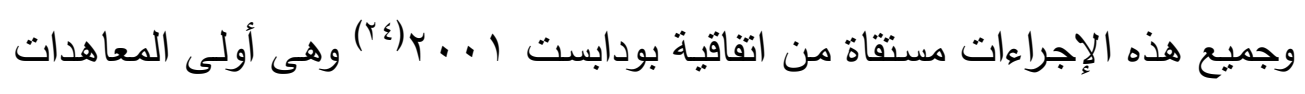

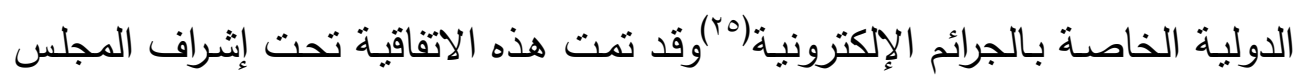




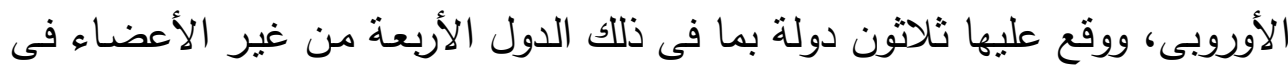

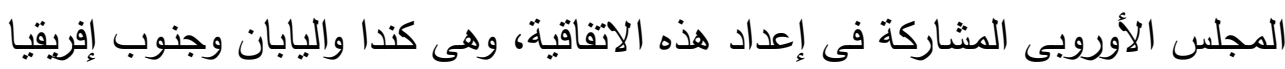

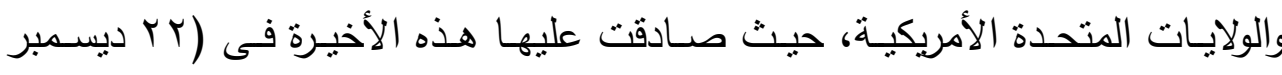

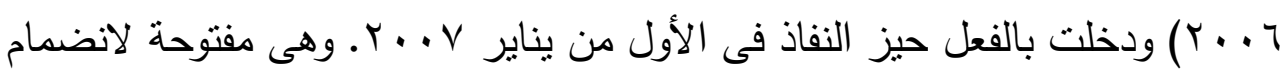

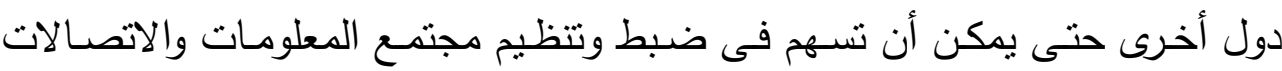

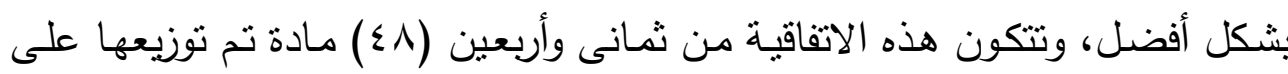

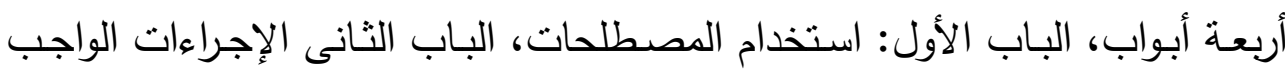

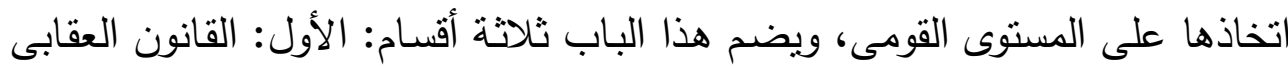

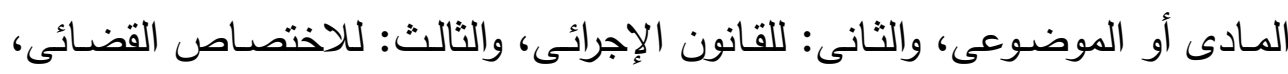
وستقتصر دراستتا على الجانب الإجرائى فقط وبصفة خاصـة الإجراءات المستحدثة الإنة التى قررتها الاتفاقية من خلال ما يلى: ا- البيانات المخرنة(الساكنة): ونتناولها من خلال إجراءين أ- التحفظ العاجل على البيانات. ب- الأمر بتقديم بيانات معلومانية متعلقة بالمشترك.

\section{أ- أتحفظ العاجل على البيانات}

المادة (7 ( ) من اتفاقية بودابست تمكن السلطات الوطنية المختصة من إصدار الأمر

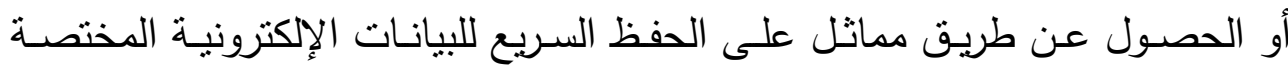

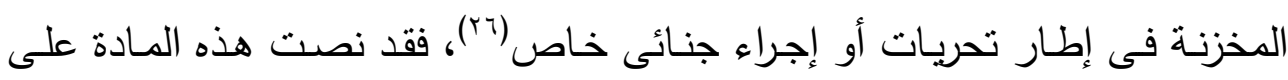

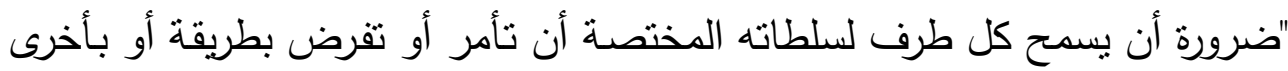
مزود الخدمة بالحفظ السريع للبيانات المعلوماتيـة المعنية" باعتبارها إجراء مؤقتًا بما لفات

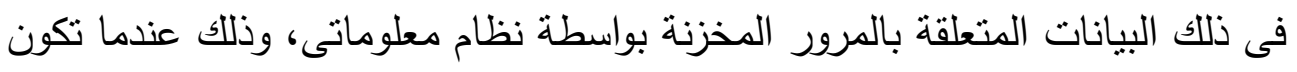


هناك أسباب تدعو للاعتقاد بأن هذه البيانات على وجه الخصوص معرضة للفقد أو

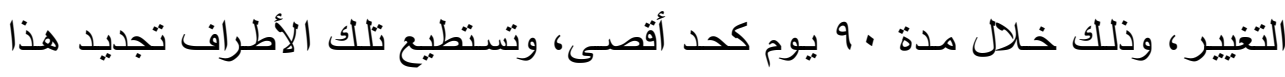
الإجراء خلال فترة الحفظ، ولا ينم إخطار السلطات الرادعة بتلك البيانات بطريقة آلية،

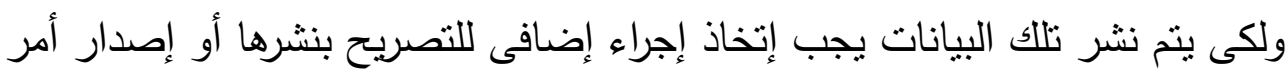

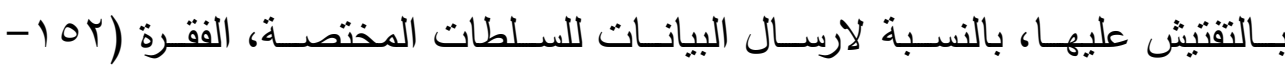
.$^{(Y Y)}(17$.

وبالتالى فإن إجراء حفظ البيانات يعد لبعض الدول، ومنها مصر سلطة قانونية جديدة، فهو أداة تحقيق مستحدثة في إطار مكافحــة الجرائم الإلكترونية، فهو يتلاءم

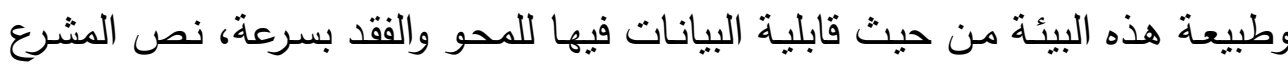

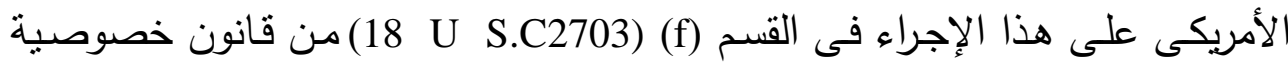
الاتصالات الإلكترونية الأمريكى (ECPA) (^ه).

\section{وفيما بإلى نتعرض لعدة نقاط:}

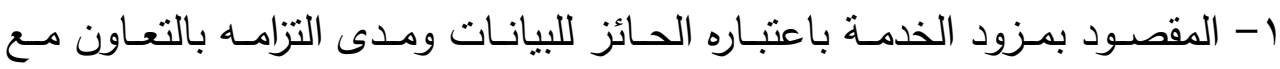

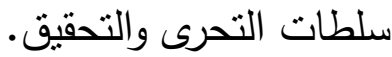
r- إلتزام مزود الخدمة بمدة معينة للتخلص من البيانات. ب- م- مهوم الحفظ السريع للبيانات.

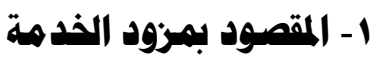
مزود الخدمات هو من يقدم خدمته إلى الجمهور بوجها عام فى مجال الاتصـالات

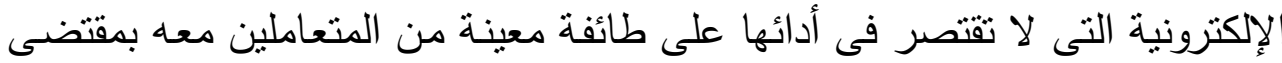

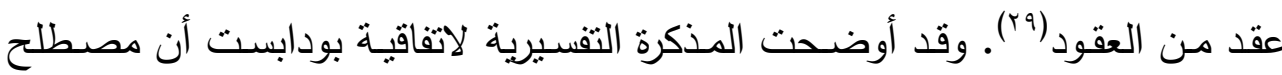

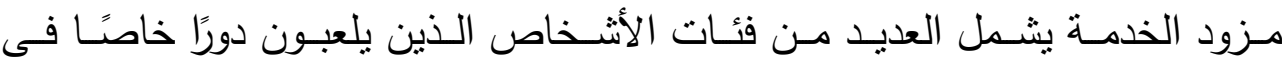


الاتصـالات أو معالجـة البيانات على النظم المعلوماتيـة، ويشير بصفة خاصـة إلى

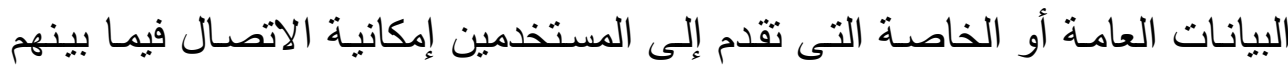

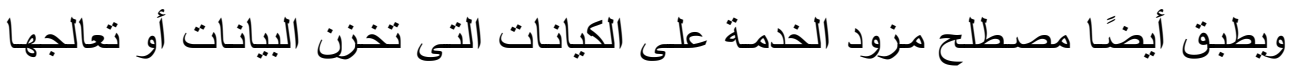

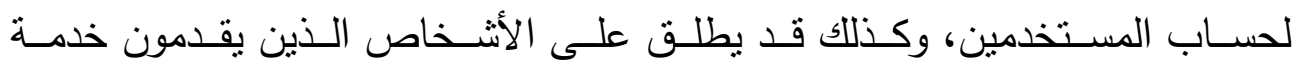
الاستضافة أو التخزين على الذاكرة بطريقة مستترة أو الاتصال بشبكة، ويفرق قانون

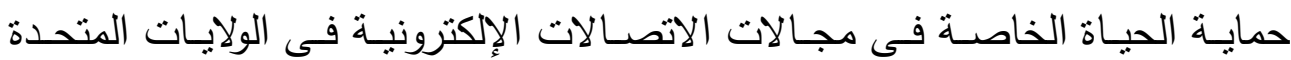

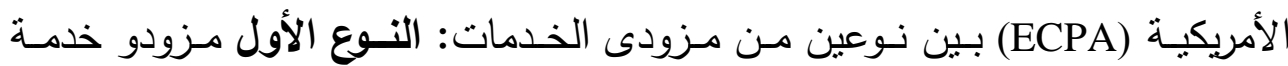
الاتصالات الإكترونية، والنوع الثانى: هم مزودو خدمة معالجة المعلومات عن بعد.

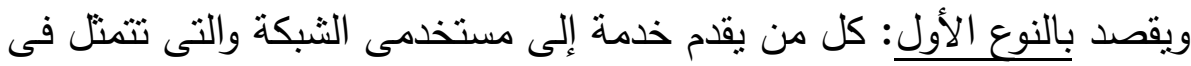

تسهيل إرسال واستقبال الاتصالات السلكية والإلكترونية(r.).

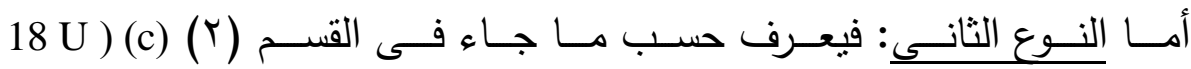

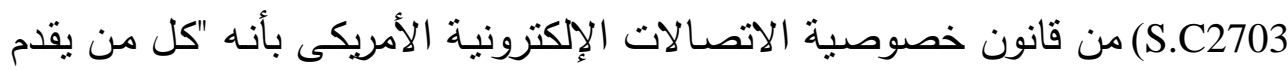
للجمهور خدمة معالجة البيانات عن بعد بوسيلة من وسائل الاتصالات الإكترونية"، ويناء عليه إذا أرسل شخص لثخص آخر رسالة عن طريق البريد الإلكترونى فإنها

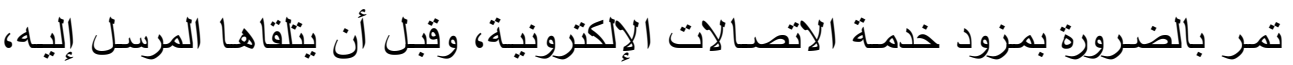

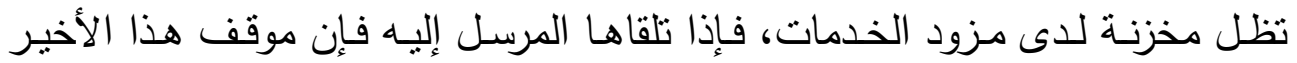

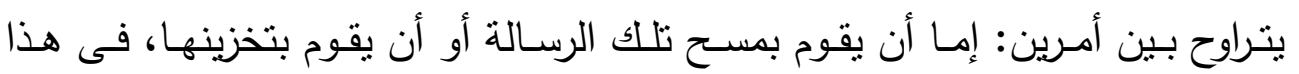
الفرض الأخير تعتبر الرسالة مخزنة لدى مزود الخدمة.

\section{r- التزام هزود الخدمة بمدة هعينة للتخلص هن البيانات}

تضع بعض التشريعات المقارنة كالقانون الفرنسى التزاما على مزودى الخدمات بإزالة

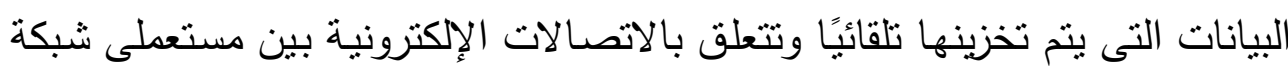


الإنترنت والتى تتعلق بهويـة المتصلين (rا(وساعة الاتصـال(rr)، بل إن قانون الأمن

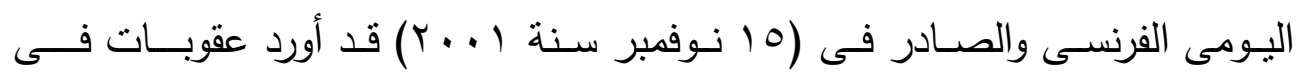

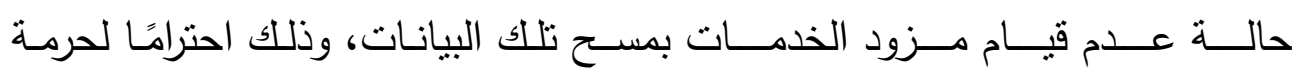
الحياة الخاصة المادة (39-3) Lئ من قانون الأمن اليومى، إلا أن هذا القانون قد أورد نوعين من الاستثناءات على هذا الالتزام:

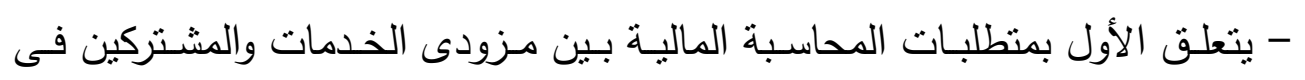

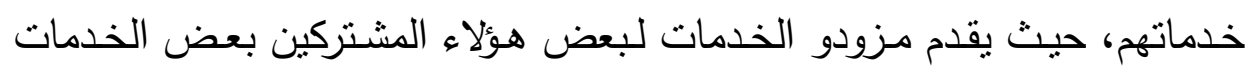

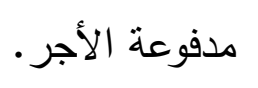

- أمسا الاستثناء الثانى فيتعلق باعتبارات التعاون من الجهات القضائية التى تبرر

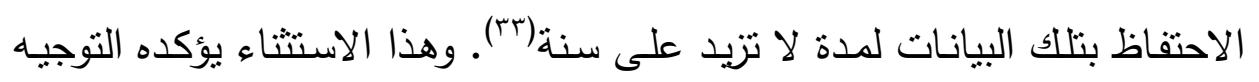

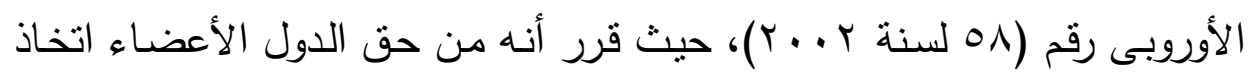

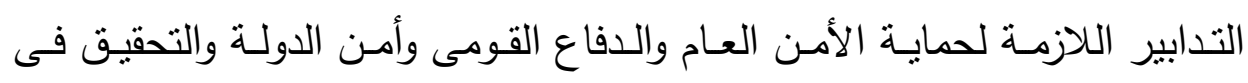

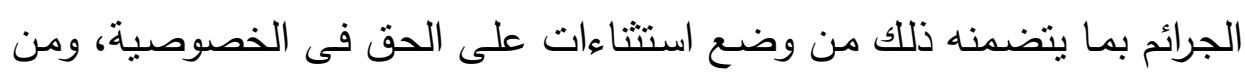

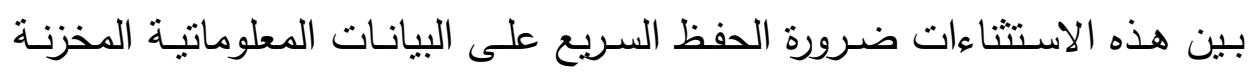
حفاظًا عليها من التلف والتغيير. وتجدر الإثارة فى هذا المقام إلى أنه ترد بعض الاستثناءات على التزام مزودى التى

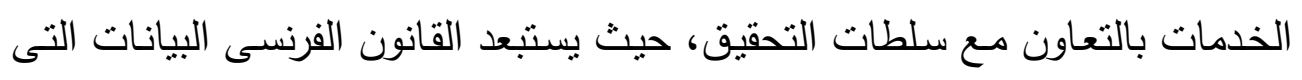

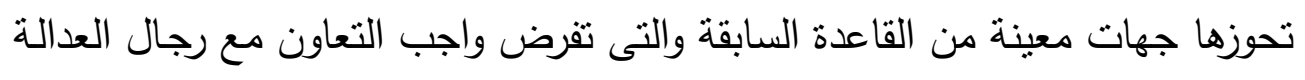

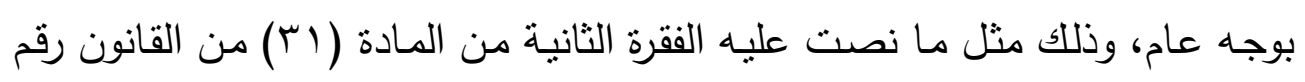

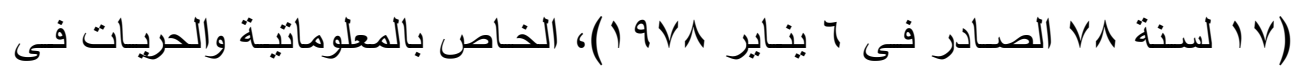

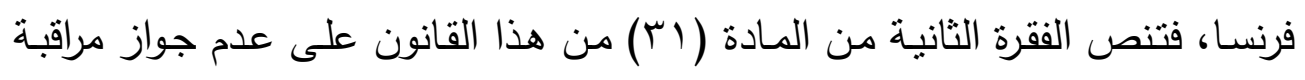


المعلومات التى تجمعها الكنائس أو أى تجمعات دينية أو فلسفية أو سياسية أو نقابية والتى تتعلق بأعضائها والمتراسلين معها.

كما تُشتثى أيضا من القاعدة السابقة أنواع معينة من المعلومات نصات نصت علينها

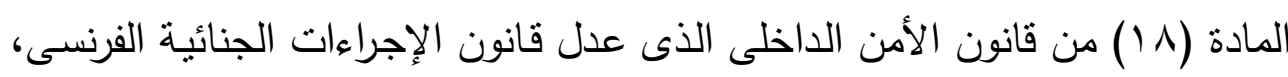

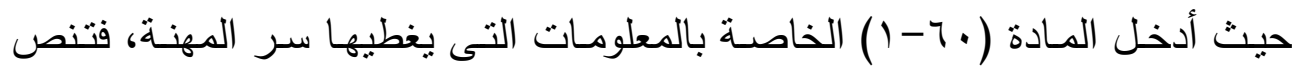

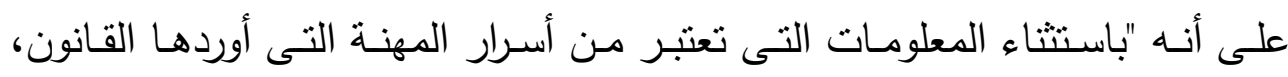

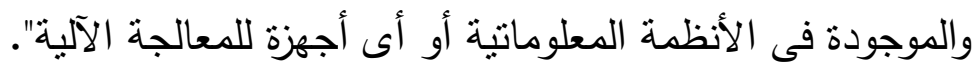

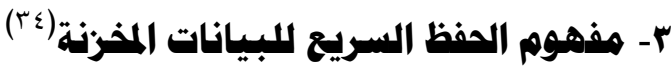

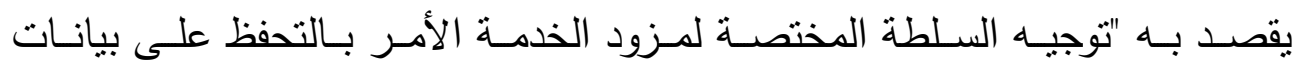

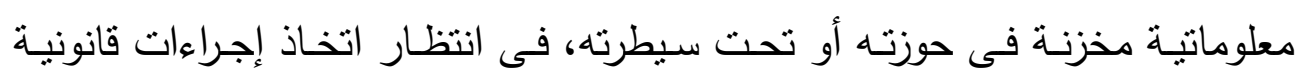

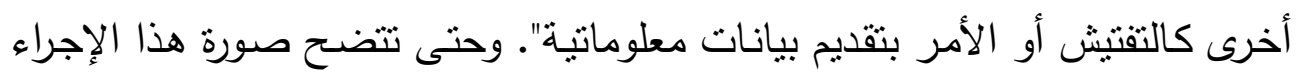

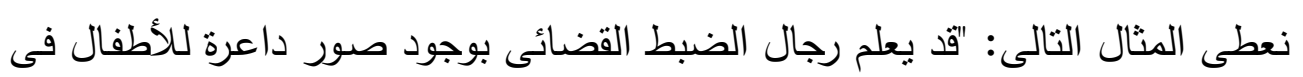

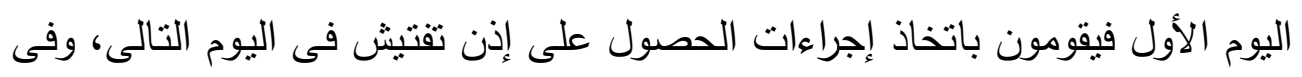

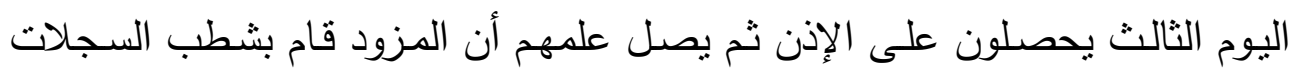

$$
\text { كالمعتاد فى اليوم الثالث المذكور". }
$$

ويتضح من المثال السابق أن الحفظ السريع إجراء أولى أو تمهيدى الهدف منهـ

هو محاولة الاحتفاظ بالبيانات قبل فقدانها.

وقد وردت الأسباب التى تدعو إلى الحفظ السريع للبيانات بالمذكرة التفسيرية

$$
\text { لاتفاقية بودابست على النحو التالى (ro): }
$$

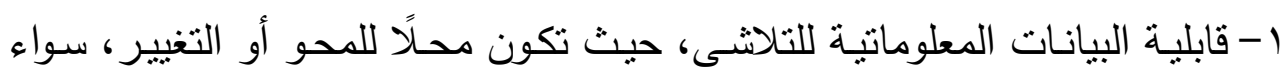

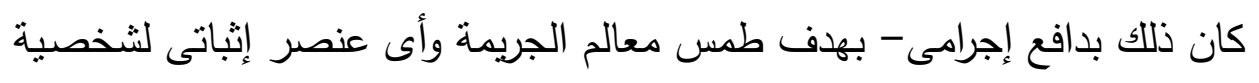


الدجرم- أو بدافع غير إجرامى وذللك فى إطار الحذف الروتينى للبيانات التى لم تعد هناك حاجة إليها. r- غالبـا ما يتم ارتكاب الجرائم الإلكترونيـة عن طريق نقل الاتصـالات عبر نظم الحاسب، حيث يمكن أن تتضمن هذه الاتصالات محتويات غير مشروعة، مثل الإنل

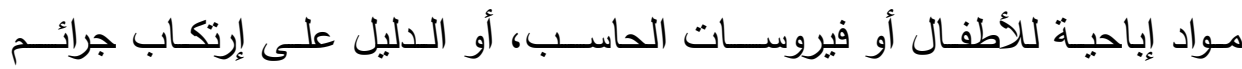

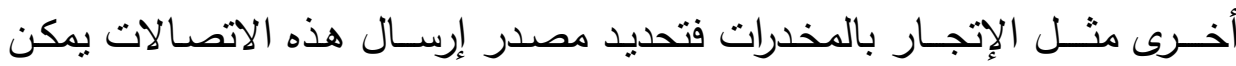
أن يساعد فى تحديد هوية مرنكبى الجريمـة.

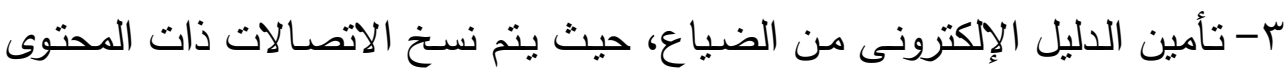

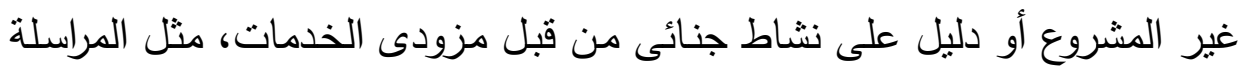

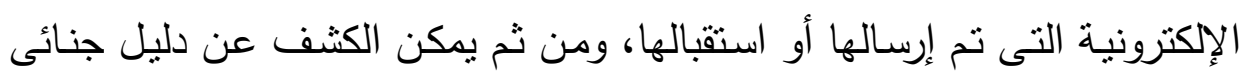
للجرائم المرتكبة.

وتجدر الإتشـارة إلـى أن البيانـات المعلوماتيـة المشـولة بـالأمر تتضـمن بينها

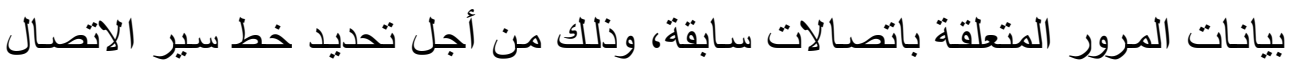

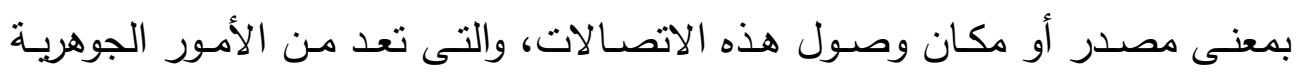

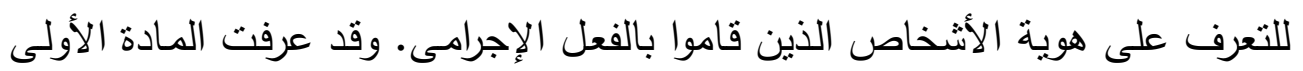
فقرة "د" من اتفاقية بودابست هذا النوع من البيانات (البيانات المنعلقة بالمرور) "بأنها

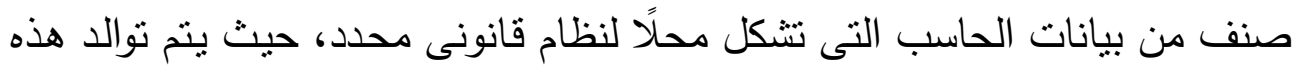
البيانات من الحواسب عبر تسلسل حركة الاتصالات لتحديد مسلك الاتصـالات من

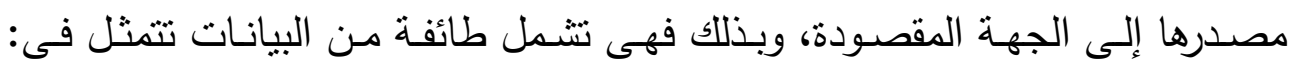
مصدر الاتصال ووجهته المقصودة، خط السير ووقت أو زمن الاتصال وفقًا لتوقيت

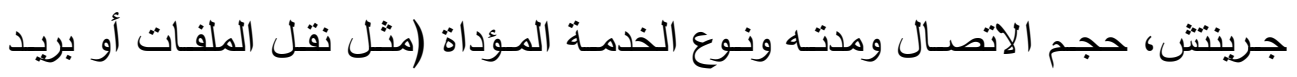


إلكترونسى أو مراسـلات فوريـة). وفى الغالب مـا يحـوز مقدم الخدمـة بمفرده بيانـات

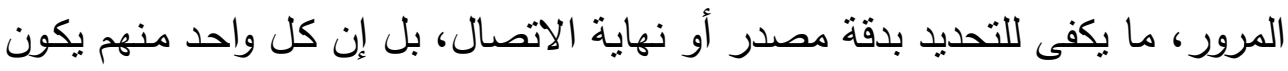

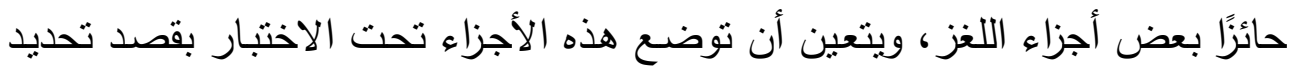
مصدرها والجهة المرسلة إليها.

\section{ب- الأهر بتقديم بيانات هعلوهاتية هتعلقة بالمشترك}

الأصل أن البيانات الشخصية المتعلقة بمستخدمى الشبكة تدخل فى إطار الحق فى هئ

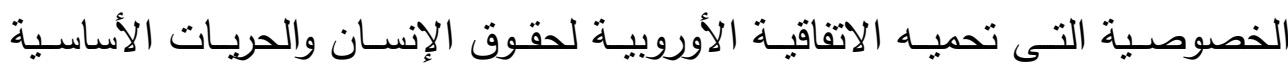

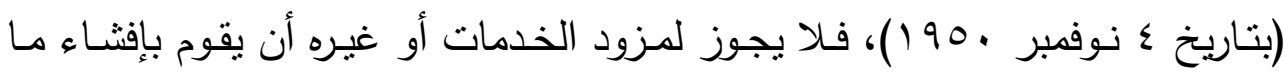

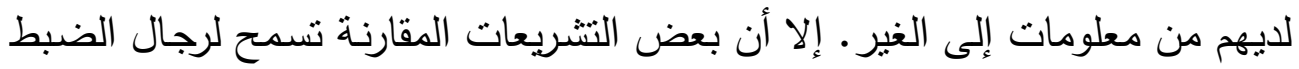

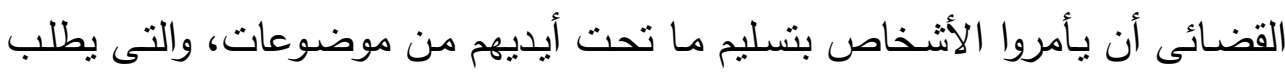
تقديمها كدليل، ومن بينها البيانات المتعلقة بالمشترك التى يحوزها مزودو الخدمات،

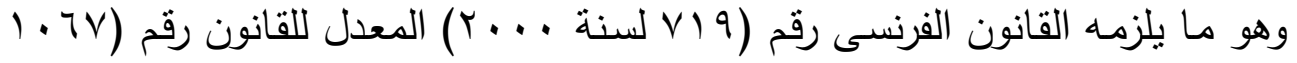

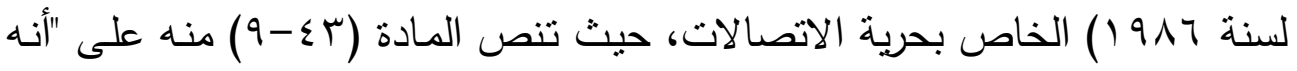

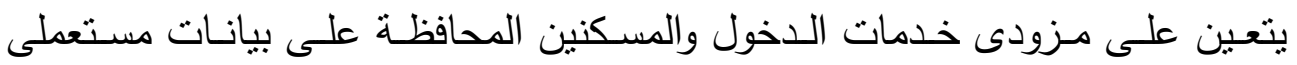
خدماتهم وذلك تمهيدا لطلب السلطات لتلك البيانات التى قد تفيد كدليل فى جريمة

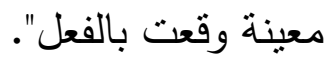

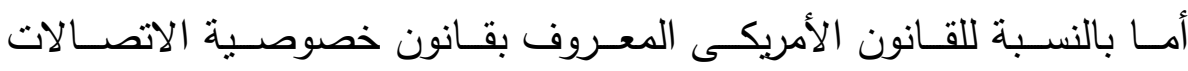
الإلكترونية (ECPA)، فقد أجاز لرجال الضبط القضائى فى إطار ما يقومون به من الارن

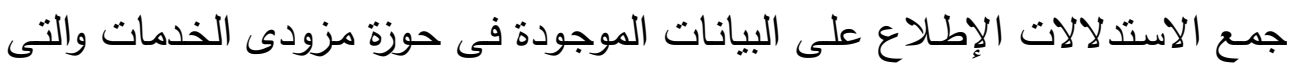
تخص مستخدمى شبكة الإنترنت، وذللك من خلال توجيه تكليف إلى مـزود الخدمات

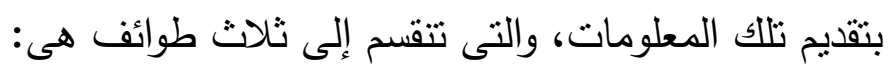


1- المعلومات الثخصيـة الخاصـة بالمشترك، مثل اسمه ورقم تليفونه وعنوانه.

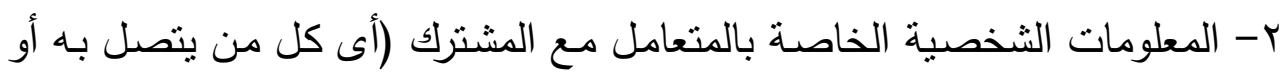
يدخل معه فى صفقة). r- المعلومات المتعلقة بمحتوى البيانات (مضمون المحادثات- مضمون الملفات).

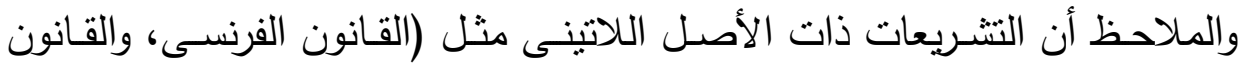

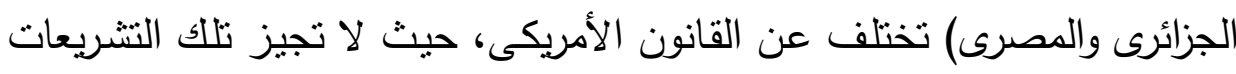

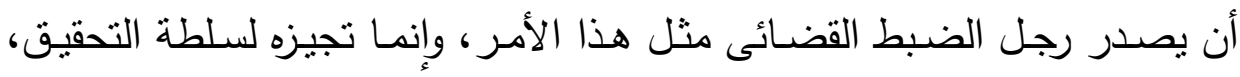

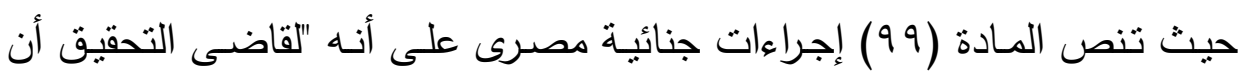

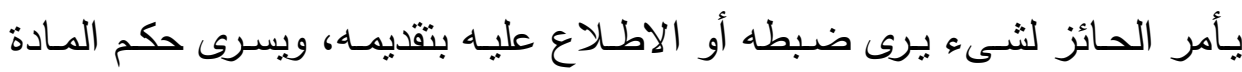
(YV乏) ذللك عن سلطة قاضى التحقيق. كما أن للمحكمة أن تصدر مثل هذا الأمر وفقًا

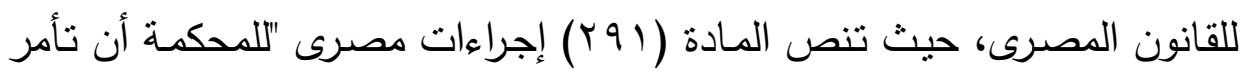

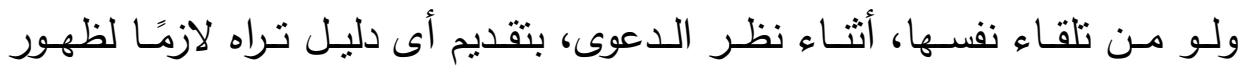

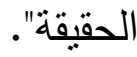

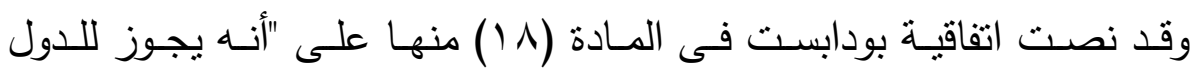
الأطراف فى تلاك الاتفاقية تمكين السلطات المختصة من إلزام مقدمى الخدمات تقديم

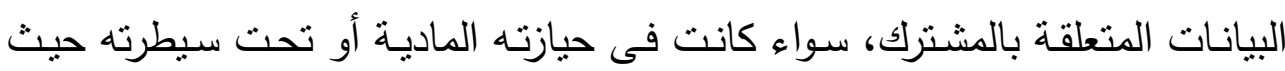

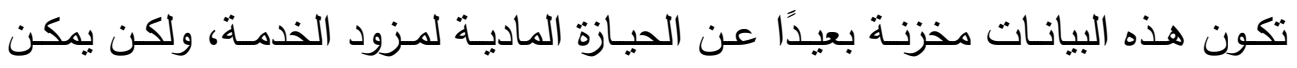

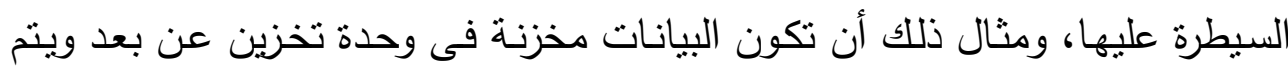

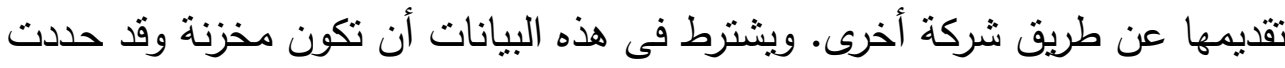
الاتفاقية المقصود بتلك البيانات بقولها إنها تتعلق: 
- بنـوع خدمـة الاتصـال التى اثترك فيها الثخص والوسائل الفنية لتحقيقها. - العنوان البريدى أو الجغرافى ورقم تليفون المشترك.

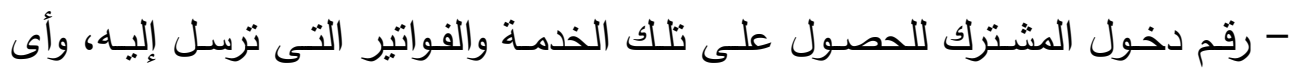

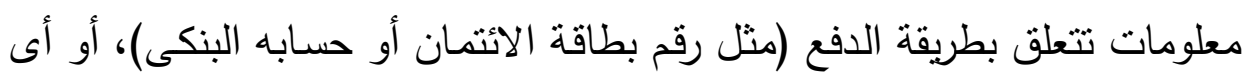

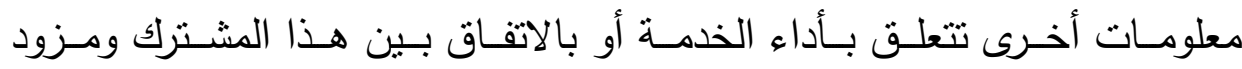

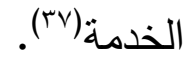

\section{ثانياً: البيانات غير المخرنة (المتمركة)}

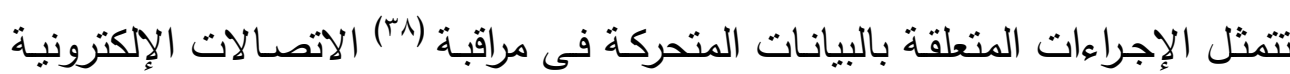

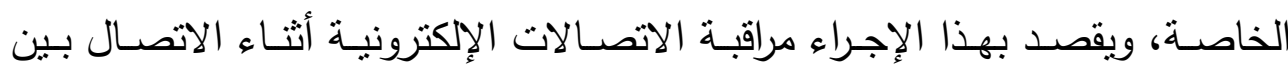

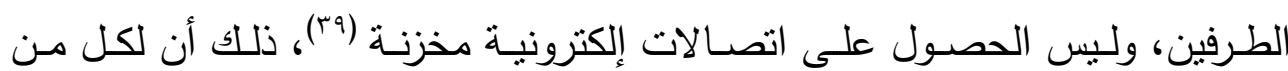
النوعين قواعد خاصـة بها، حيث إن ضمانات الحصول على الأولى أكثر شدة من النه

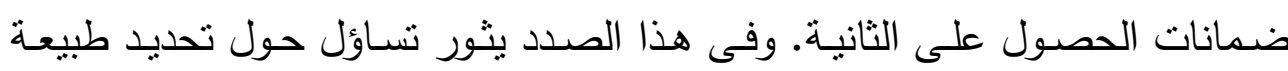
البريد الإكترونى غير المفتوح الموجود فى صندوق خطابات مقدم خدمات الإنترنت

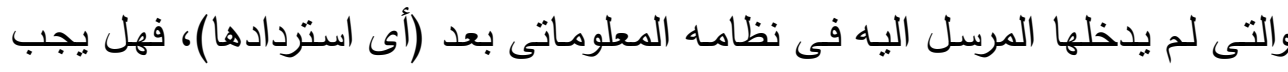
اعتبارها بيانات معلوماتية مخزنة، وبالتالى تطبق عليها الإجراءات المتعلقة بالبيانات

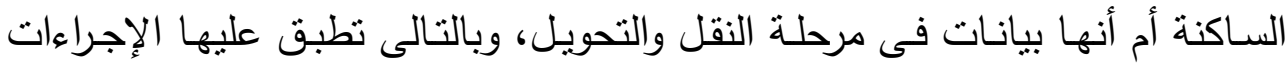
المتعلقة بالبيانات المتحركة والمتمثلة فى مراقبة الاتصالات الإكترونية. ومن ثم لا يتم

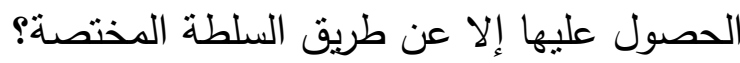

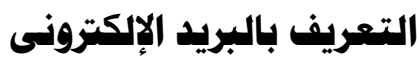

يعتبر البريد الإلكترونى من أهم التطبيقات الإلكترونية التى توفرها شبكة المعلومات

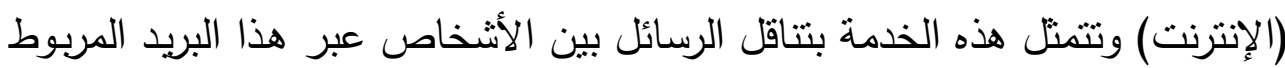


بشبكة الإنترنت وعلى الرغم من المزايا التى تتمتع بها خدمة البريد الإلكترونى التىى

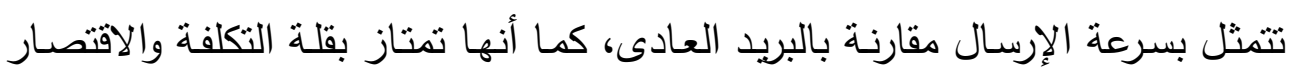

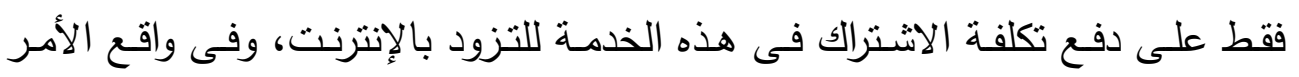

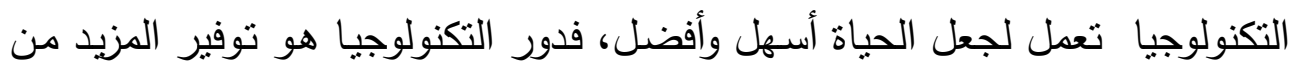

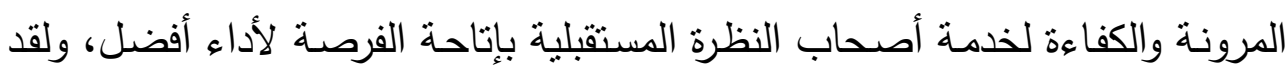

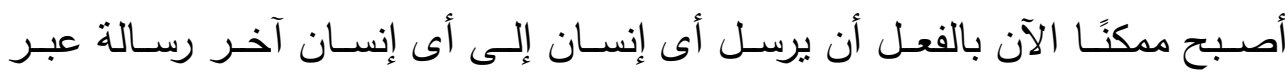

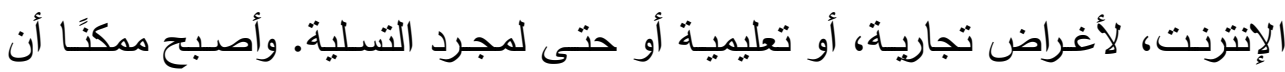

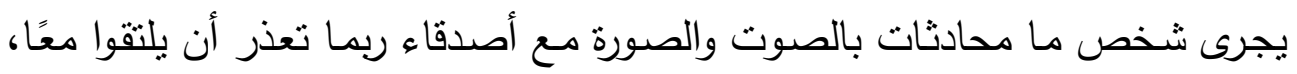
وذللك من خلال نظم تتغيل الكمبيوتر - التى توفر تطبيقات متعددة أخرى غير البريد

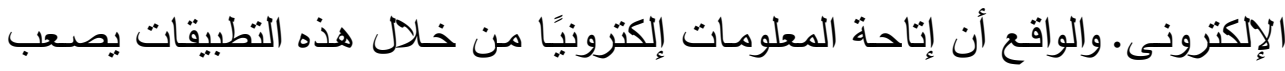
"توصيلها" إلى من لا يستخدم الكمبيوتر (.؛.).

\section{البريد الإلكترونى كوسيلة لإرتكاب الجريمة وكمصدر للدليل}

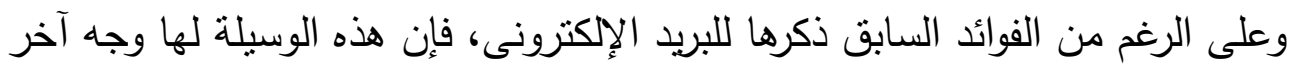
قد يوصف بالقبح، يتمثل فى كثرة الجرائم التى ترتكب بواسطتها، والتى تمثل انتهاكًا

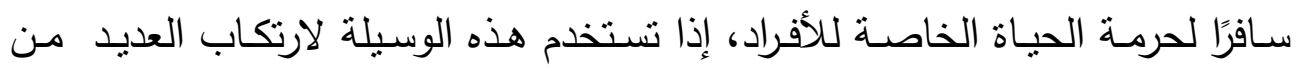

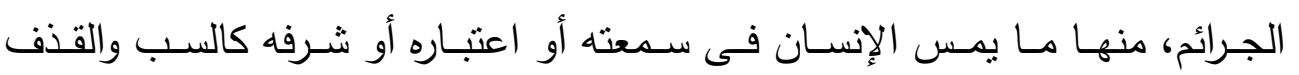

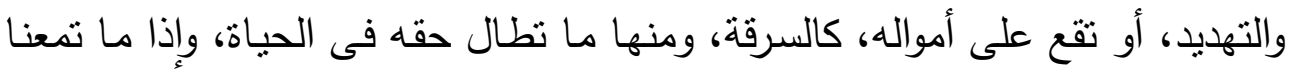

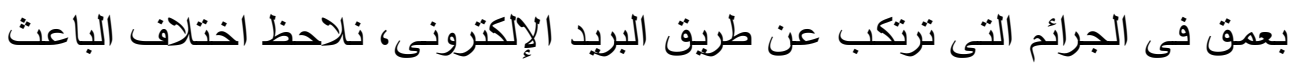

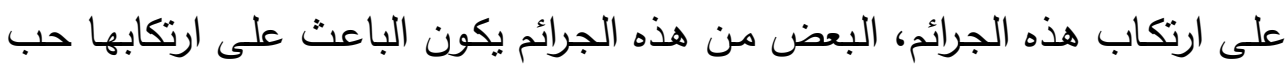

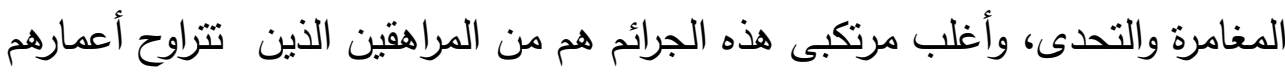

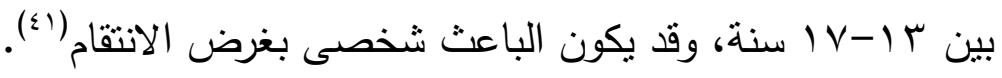


ومسن التسـاؤلات التـى تتعلق بالبريــا الإكترونسى، مـا مــى التثـابه بـين الرسـائل

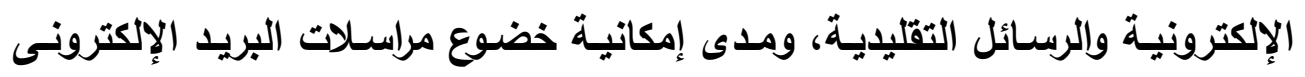
للقواعد التقليدية دون حاجة لوضع قواعد خاصة بها؟ تنص مادة (90) إجراءات جنائية مصرى على أن "المراسلات هـى الرسائل والجرائد

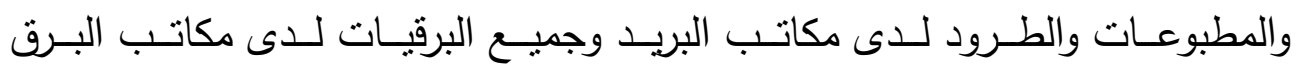

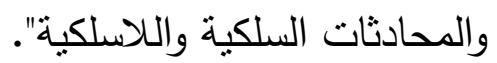

نلاحظ فـى هذا النص أن المشـرع المصـرى قد أدخل المحادثات التليفونيـة

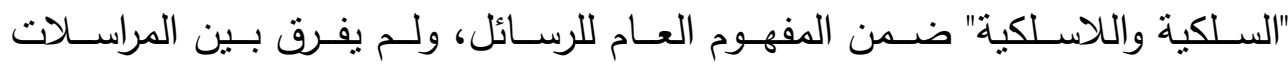

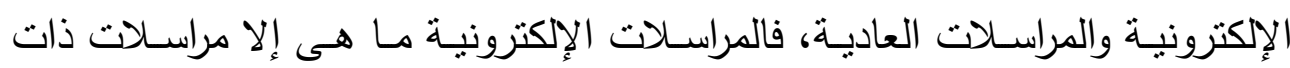

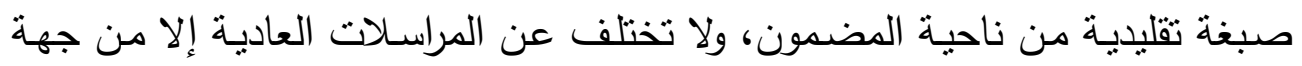

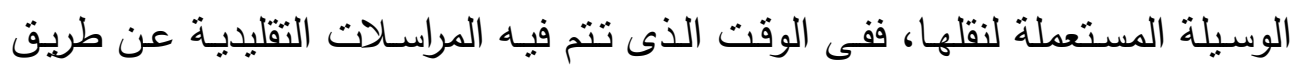

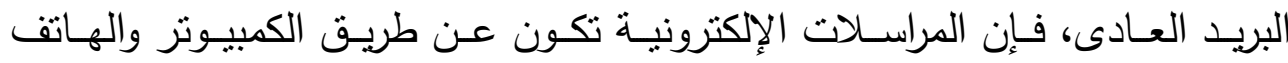

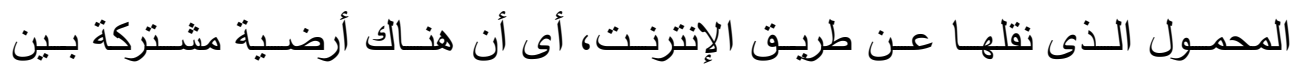

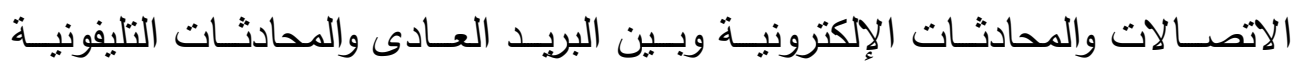

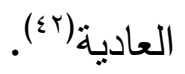

ونرى المشـرع المصـرى غير موفق فى المسـاواة بين المراسـلات الإلكترونيـة

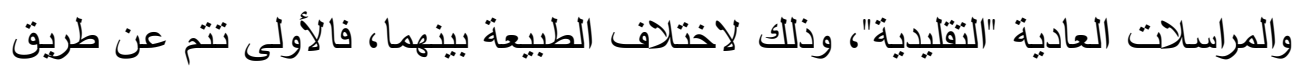
شبكة الإنترنت والبريد الإلكترونى، فى حين تتم الأخرى عن طريق الخطابات المرسلة

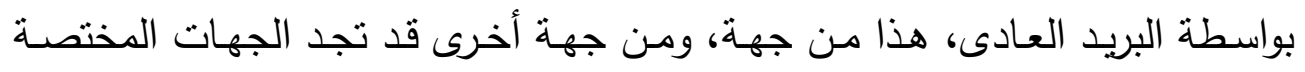

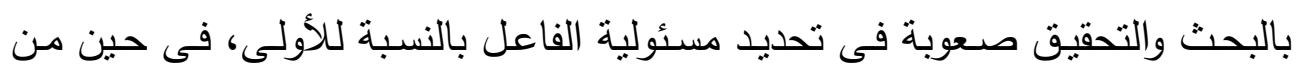
السهل تحديد الفاعل ومسئوليته بالنسبة للنانى. 
وفيمـا يتعلق بالقواعد التى تطبق على المراسـلات الإلكترونيـة نجد المشـرع

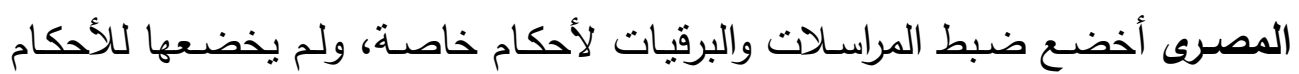

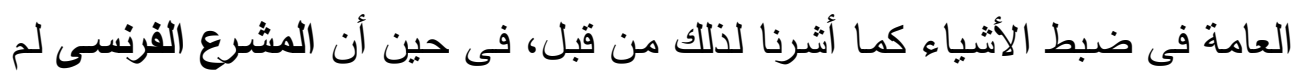

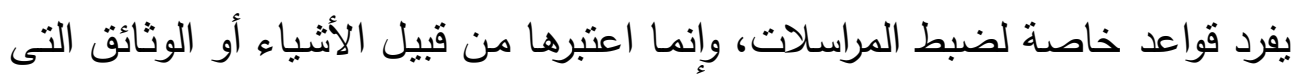

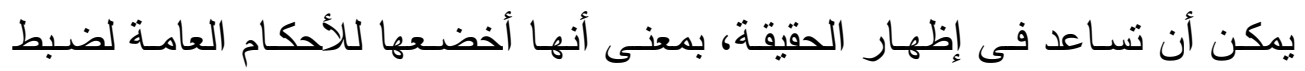

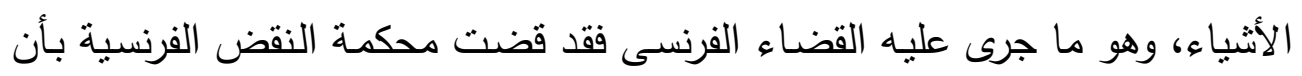

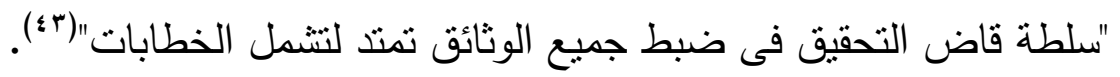

\section{الاتصالات الإلكترونية}

قد أعتبر الششرع الأمريكى الاتصالات الإكترونية المخزنة من قبيل البيانات الساكنة،

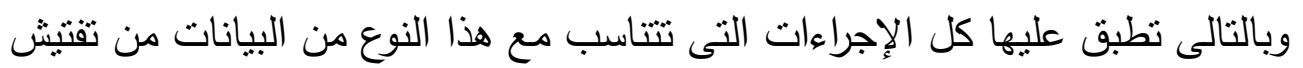

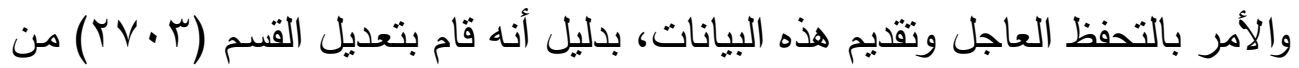

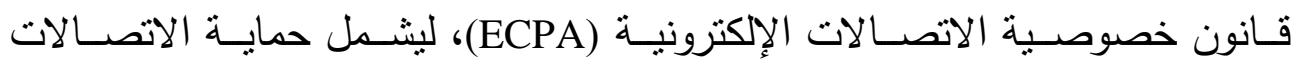

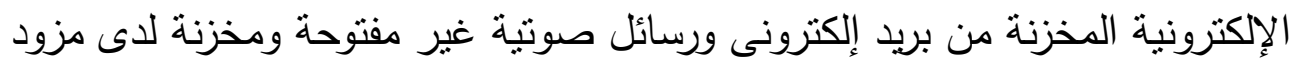
الخدمـة. وقد تم تأكيد هذه القاعدة فى العديد من التطبيقات القضـائية مثل قضيدية (United States v. Smith) السلكية وهى فى حالة التخزين الإككترونى. وقد ميزت اتفاقية بودابست بين نوعين من البيانات المعلوماتية محل المراقبة،

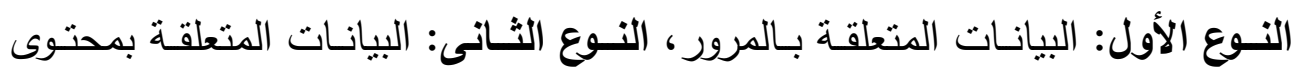
الاتصال، وبالنسبة للنوع الأول فإن المادة الأولى ( () من الاتفاقية قد عرفتها بأنها "كل البيانات التى تعالج الاتصالات التى تمر عن طريق نظام معلوماتى، والتى يتم إنتاجها بواسطة هذا النظام المعلوماتى بوصفه عنصرا فى سلسلة الاتصال، مع تعيين 
المعلومات التالية: أصل الاتصال، مقصد الاتصـال أو الجهة المقصودة بالاتصـال،

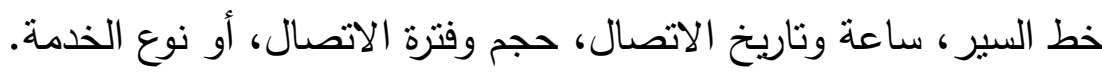

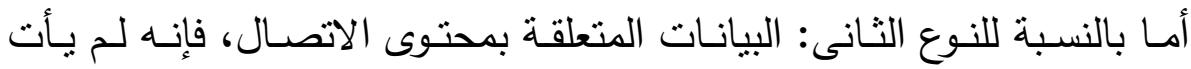
تعريف لها فى الاتفاقية لكنها تشير إلى المحتوى الإخبارى للاتصسال، بمعنى مضمون

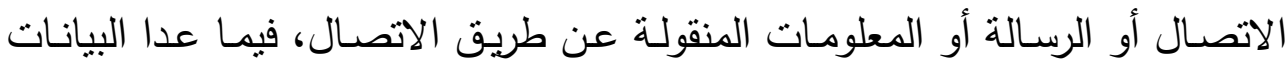

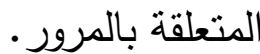
ويلاحظ أن هناك نوعًا من التقارب بين هذين النوعين من البيانات، من حيث المعنى إلا أنهما مختلفان تمامًا من حيث درجـة المسـاس بـالحق فى الخصوصية، حيث يكون ذلك أكثر أهية بالنسبة لمراقبة محتوى الاتصـال أو المراسلة، ومن ثم

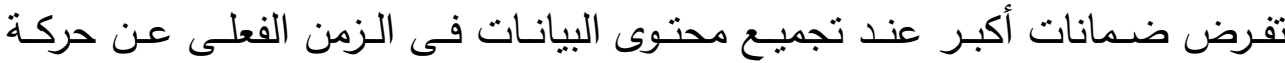

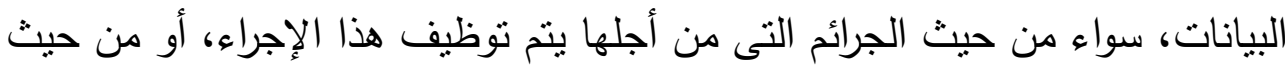
السلطة المختصة بإصدار أمر المراقبة. وقد أكدت اتفاقية بودابست هذا التمييز حيث أدرجت كل إجراء على حدة تحت الته التهاه

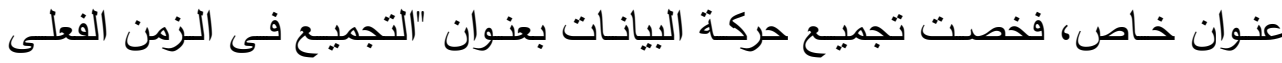

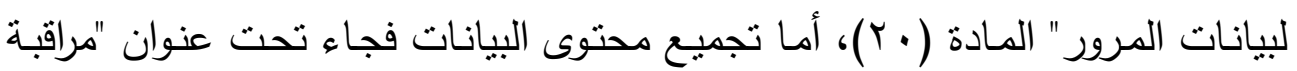

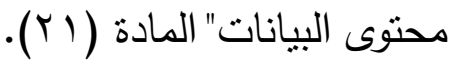

فى حين تضـع بعض الدول مفهومًا موحدًا لكل من تجميع حركة البيانات

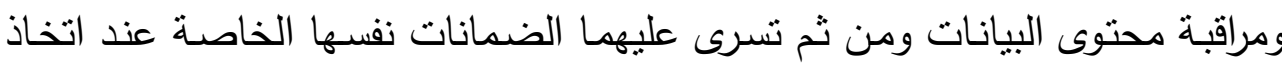

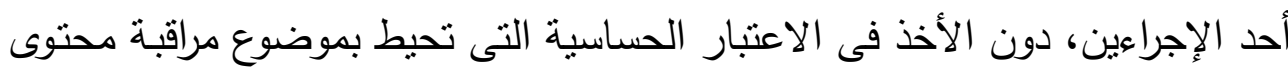
البيانات. ويرجع السبب فى ذلك إلى عدم وجود تمييز فى القانون الذى لا يوجد فيه 
اختلافات حول المصلحة فى الخصوصية أو لنتابه إجراءات التجميع التقنى ومن هذه

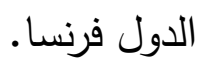

ولا جدال أن حق الإنسان فى الخصوصية ليس حقًا مطلقًا، بل مقيدًا بالمصلحة

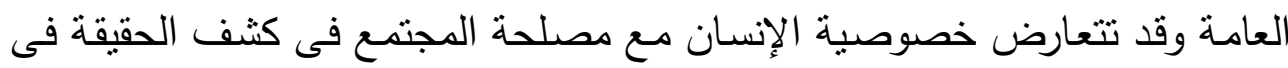

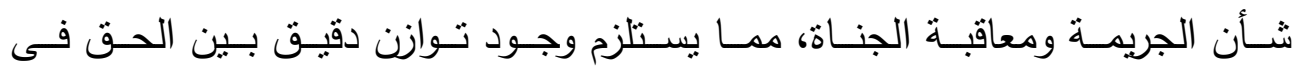

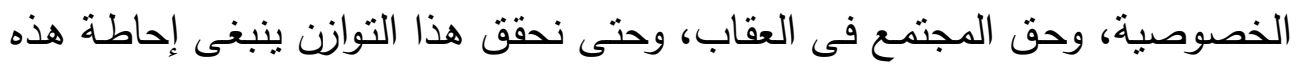

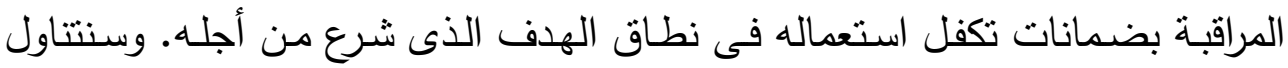

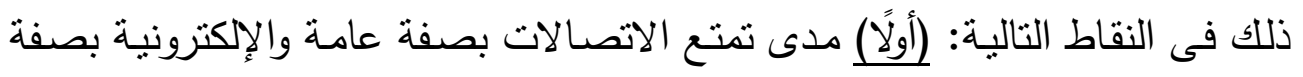

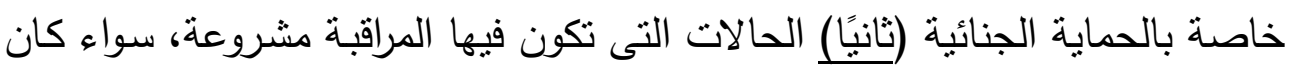
ذلك بدون الحصول على إذن مسبق أو بناء على إذن.

\section{أولاً: حرهة الاتصالات الإلكترونية الخاصة وهدى تمتعها بالهماية الجنائية}

مما لا شك فيه أن مراقبة الأحاديث الخاصة تمس بحق الإنسان فى الخصوصية وما

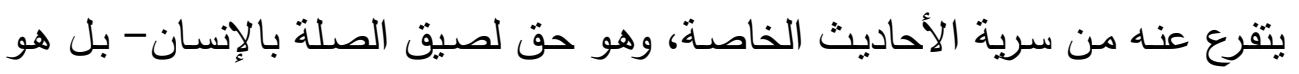

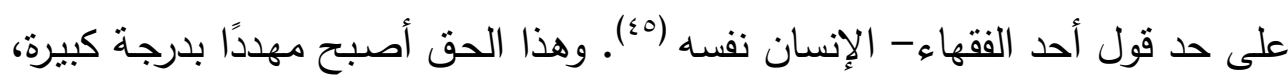
نتيجة للتطور التكنولوجى الذى أدى إلى إفراز أجهزة للمراقبة ذات تثقنية عالية، تلتقط

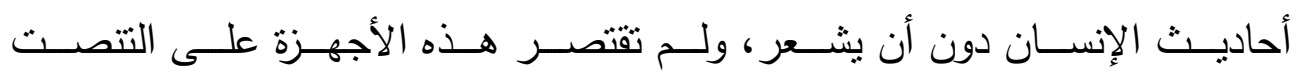
(interception)

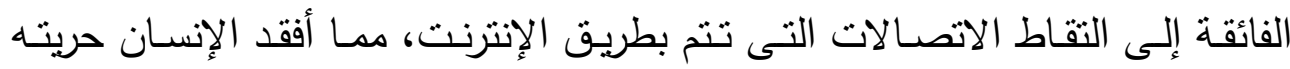

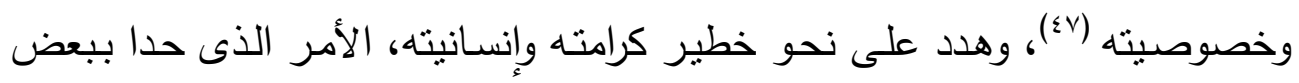

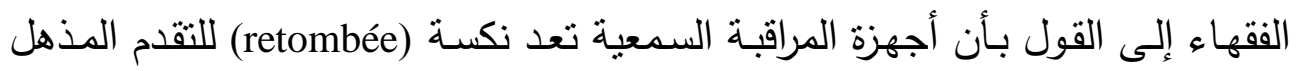


للتقنيات الحديثة، ولقد حرصت أغلب النتريعات على توفير قدر كبير من الحماية الجنائية لسرية الاتصالات الخاصة للأفراد (^).

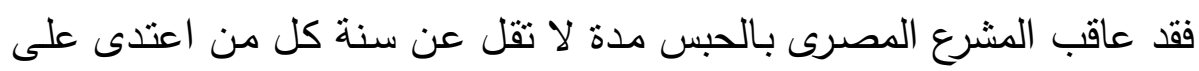

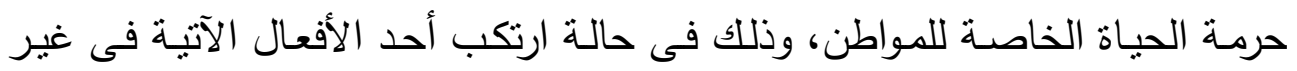

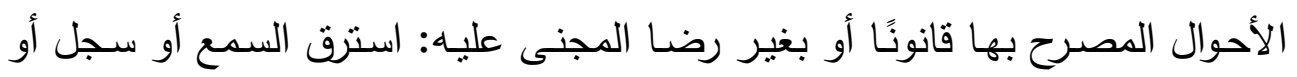

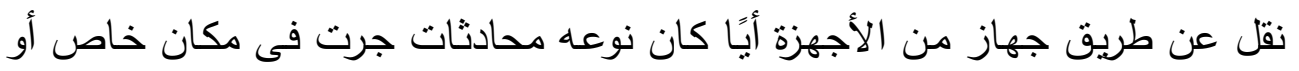

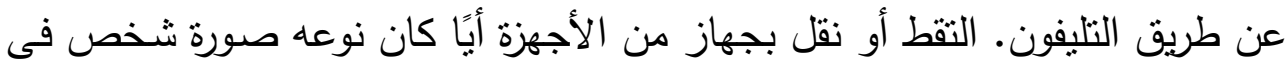

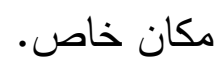

ووفقًا للمـادة (9 · م مكرر) عقوبـات مصرى، نلاحظ أنها تخص المحادثات

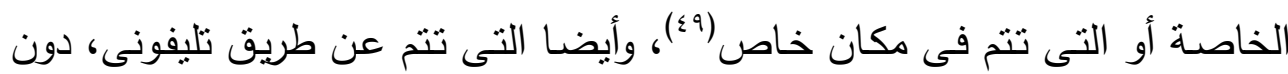

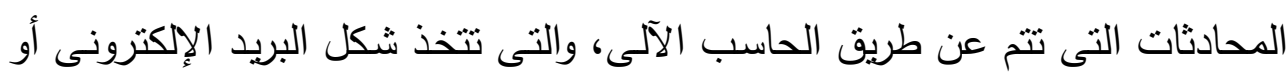

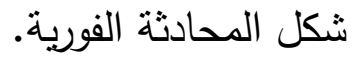

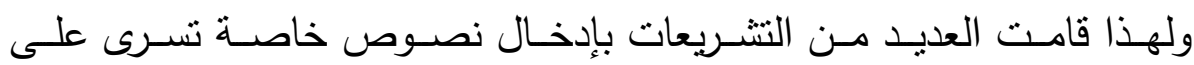

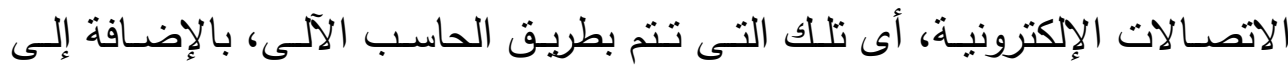

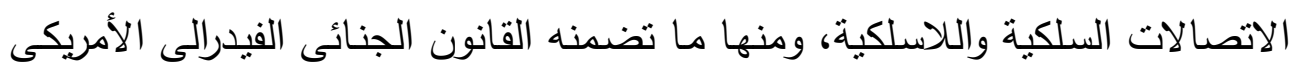
(Chapter 119, Part 1, Title 18 Sec. 2511) الإكترونية، مساويًا فى ذلك بينها وبين الاتصالات السلكية، حيث نص على عقاب

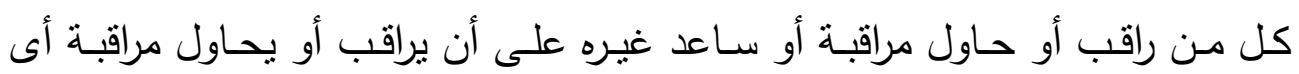
اتصال سلكى أو شفوى أو إلكترونى.

ولذلك نرى ضـرورة أن يتدخل المشرع المصرى لسن قوانين خاصـة، لتنظيم

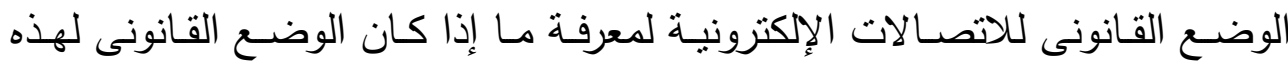


الاتصالات تسرى عليه القواعد الخاصة بالاتصالات السلكية أم لا. خاصـة، وأن هذا النوع من الاتصالات وإن كان يتم عن طريق خط تليفونى، فما هو إلا وسيلة للاخول على الثبكة فقط.

\section{ثانياً: المراقبة المشروعة للاتصالات الإلكترونية الخاصة}

ذكرنـا سلفًا أن الأصل هو حظر مراقبـة الاتصـالات الإلكترونيـة الخاصـة، إلا بإذن

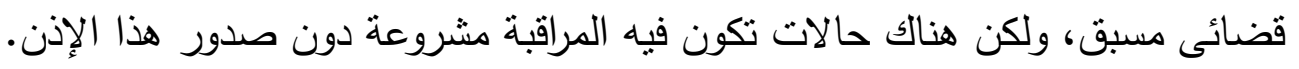

\section{ا - سلطة هزود الخدهات فى هراقبة النظام دون إذن}

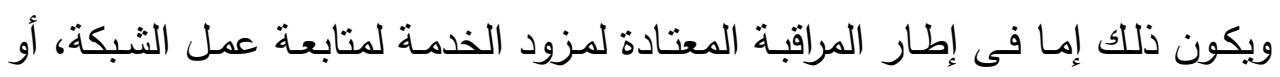

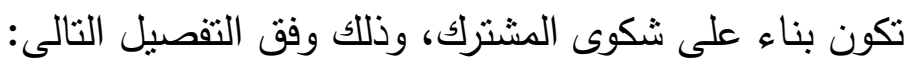

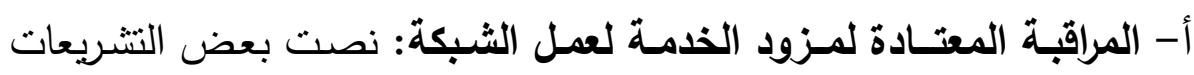

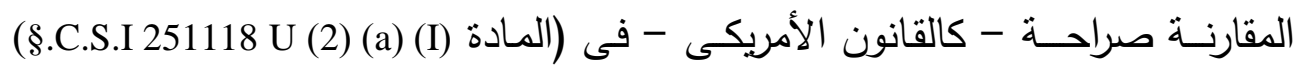

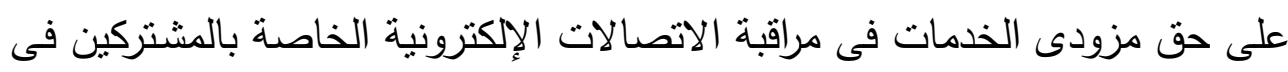

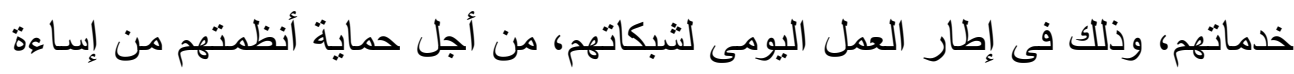

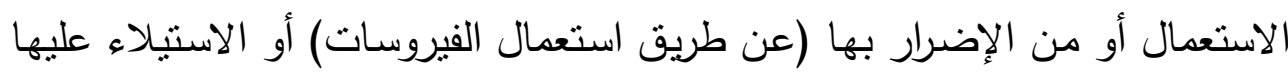
بالسرقة مثنلًا (0.).

ومن النطبيقات القضائية على هذا النوع من المراقبة ما قضى به من أنه يجوز

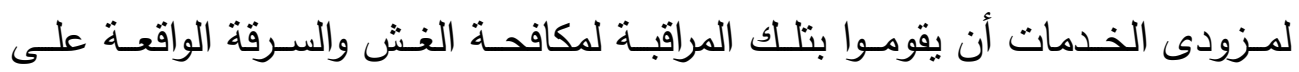

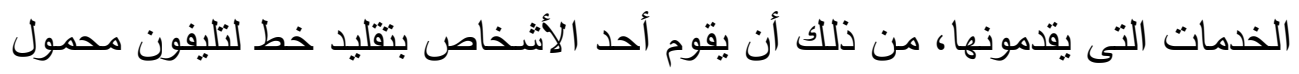

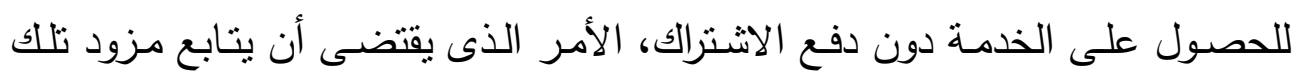

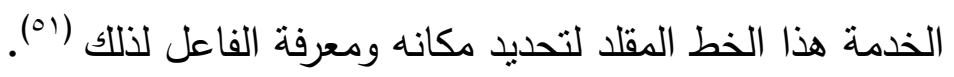


ومن الجدير بالذكر أن المشرع الأمريكى، لم بطلق سلطة مزودى الخدمات فى الثى ممارسة نلك الرقابة، بل اشترط عدة شروط ينبنى توافرها لصحة هذه الرقابة وتتمثل فيما يلى : فمارسه :تل

1- أن يكون مزود الخدمات مجنيًا عليه فى جريمة.

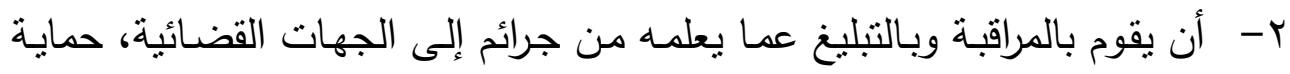
لحقوقه وليس قياما بدور المساعد للمباحث فى التحريات التى يقومون بها.

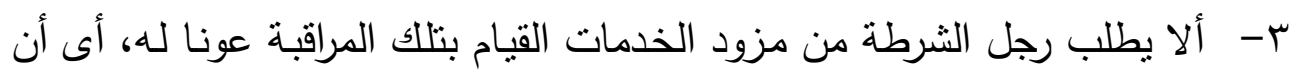
المبادرة بالتبليخ يجب أن تأنى من جانب مزود الخدمات.

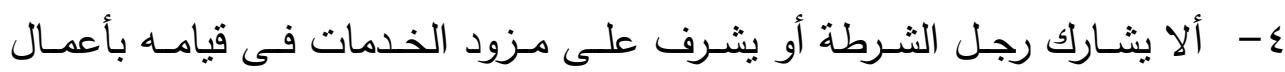

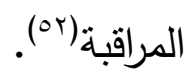

ب- المراقبـة بنـاء على شكوى المشـترك: اختلفت التشريعات المقارنـة حول

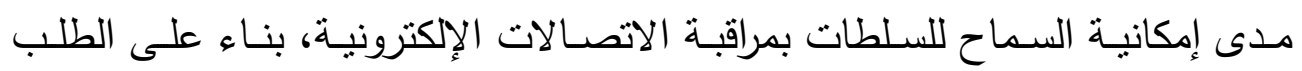

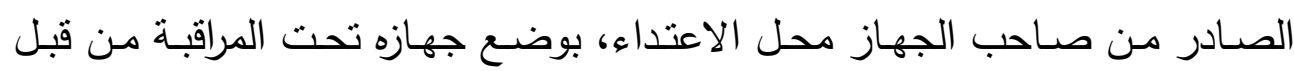

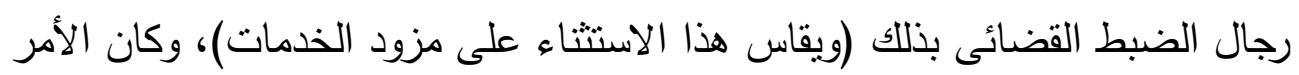
يدور بين رأيين: أحدهما مؤيد والثانى معارض لهذه المراقيط لذانة.

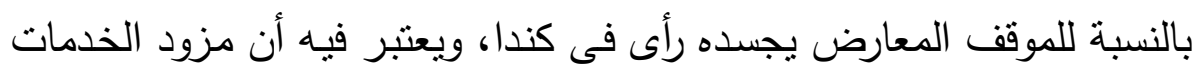

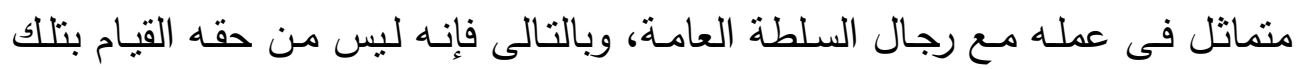
الرقابة وتلك التسجيلات بدون إذن، فإذا قام بذللك، فإنه يخالف حكم المادة (ع ب فقرة r r r من ميثاق الحقوق والحريات الكندى. أما بالنسبة للموقف المؤيد لهذا النوع من المراقبة، فيجسده القانون الأمريكى،

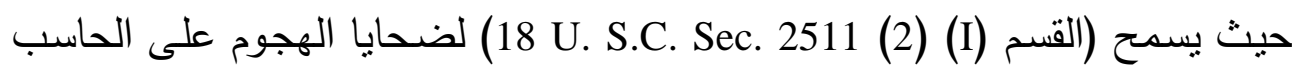


بتفويض السلطات لمراقبة الاتصالات السلكية والإلكترونية التى يتم بثها إلى أو من الجهاز محل الاعتداء. ويلزم لتوافر هذا الاستثناء اجتماع أريعة شروط وهى:

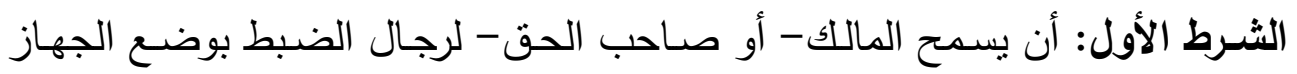
الخاص به تحت المراقبة. الثرط الثانى: أن يتم ذلك فى إطار تحقيق جنائى قائم.

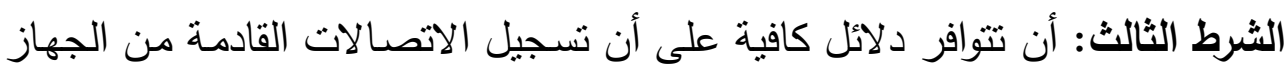
الصادر منه الإعتداء يفيد فى كثف الحقيقة.

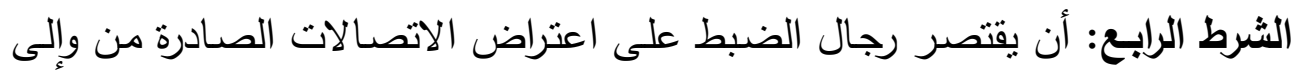
الأجهزة محل التحقيق. وفى تحديد مفهوم "المعتدى على النظام"، يستبعد القانون الأمريكى من هذا

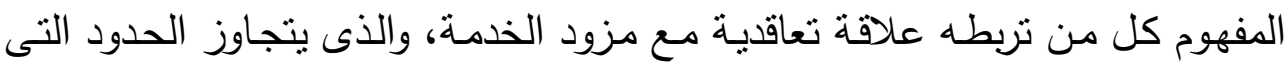

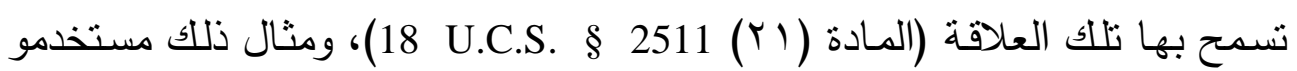

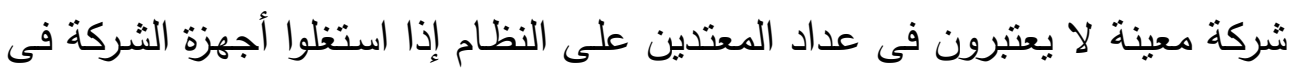

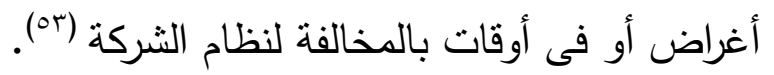

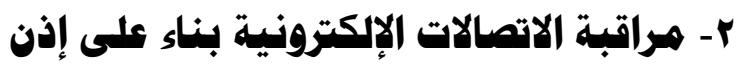

مما لا شك فيه أن الحماية التى يكفلها المشرع للاتصالات العادية لا يقتصر نطاقية الانها

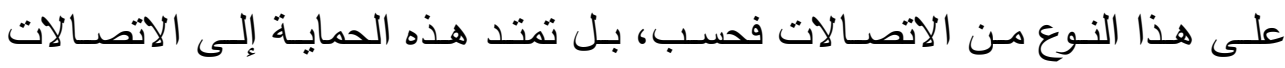

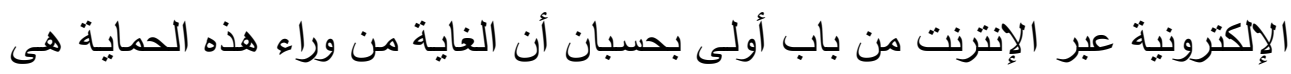

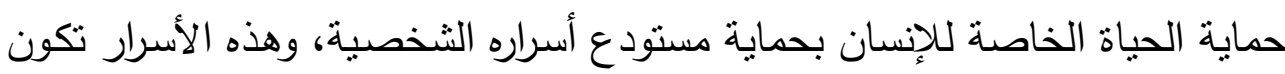
أكثر انتهاكا إذا ما استخدمت الوسائل الإلكترونية فى الوصول إليها، ومن ثم فإنها 
تكون فى حاجة إلى حماية أكثر من تلك الحماية التى تحتاجها الاتصالات العادية.

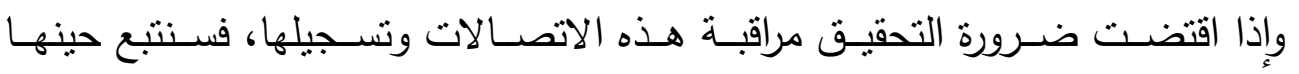

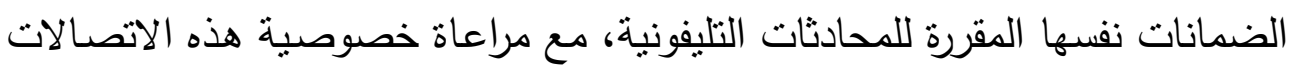
الحديثة. وتتمنل أهم الضمانات القانونية فيما يلى:

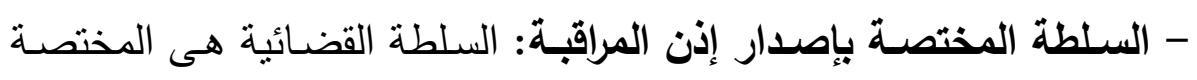

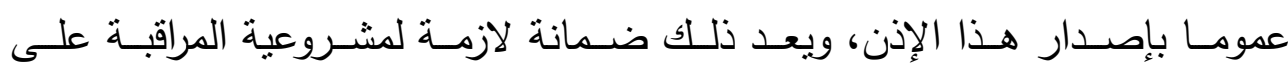

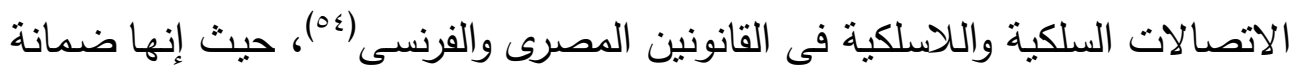

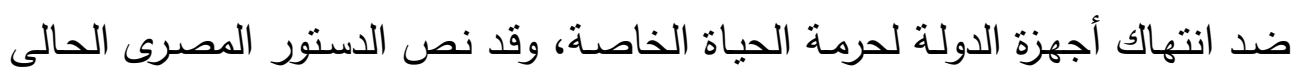

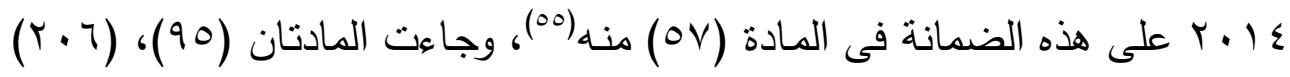

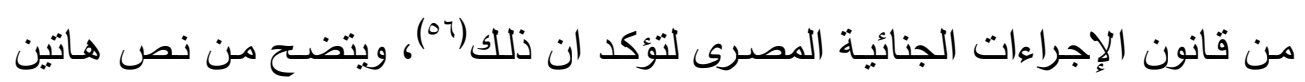

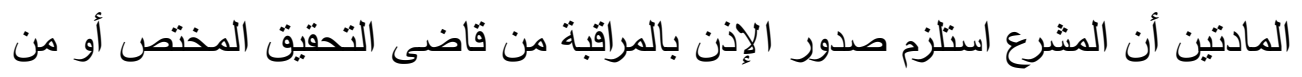

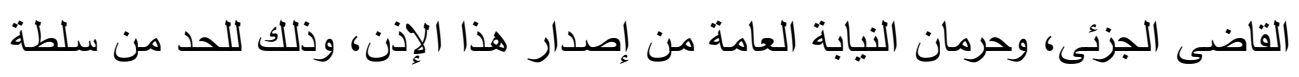

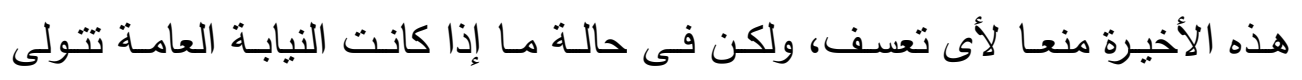

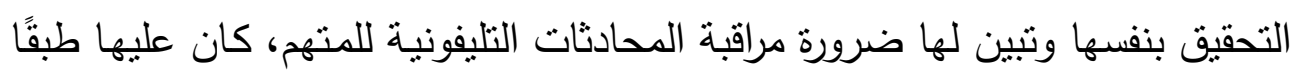

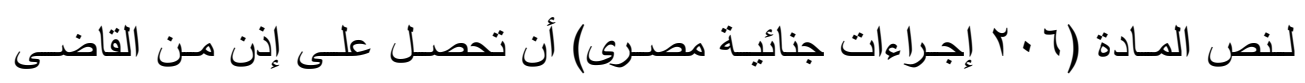

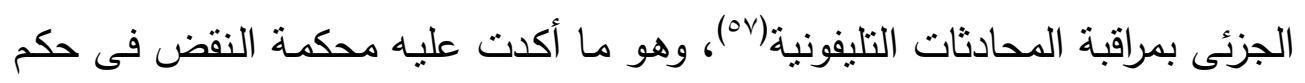

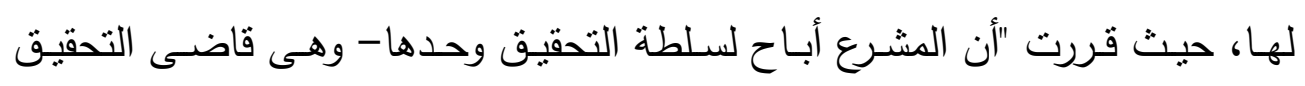

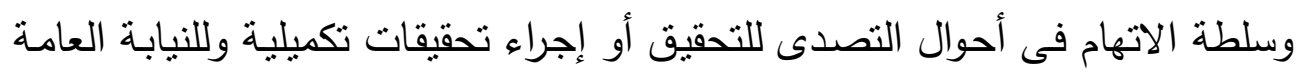

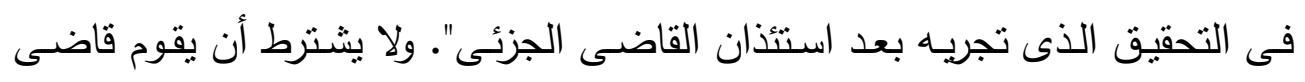

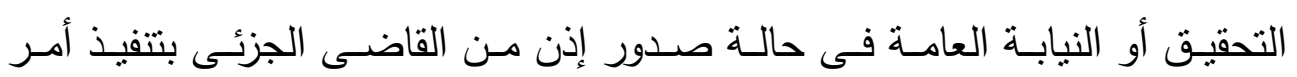
المراقبة، بل لهما أن يعهدا بذلك لمأمور الضبط القضائى (ه). 
ونرى أن الطبيعة الخاصـة التى يتمتع بها الدليل الإكترونى من حيث سرعة

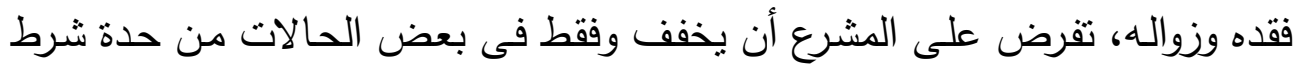

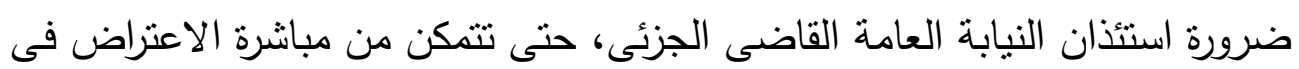

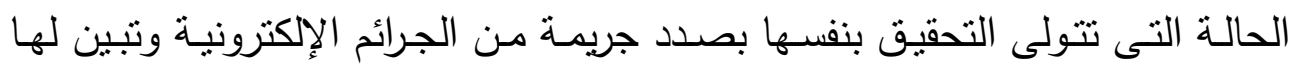

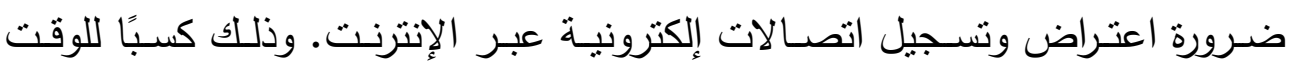
للتحفظ على الدليل وضبطه.

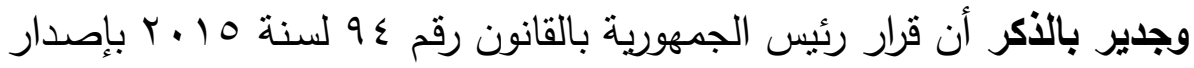

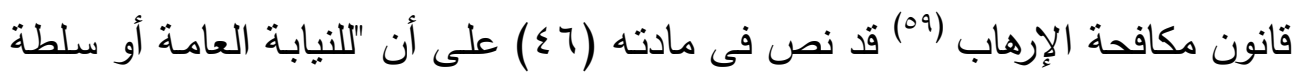

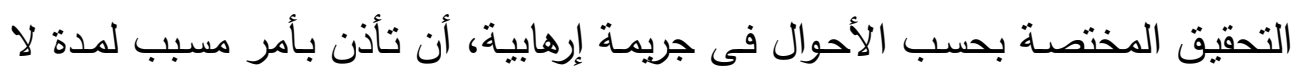

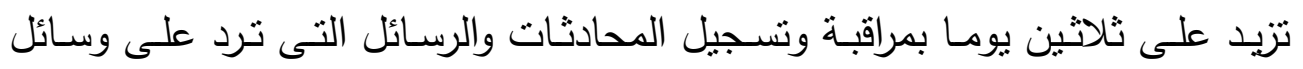

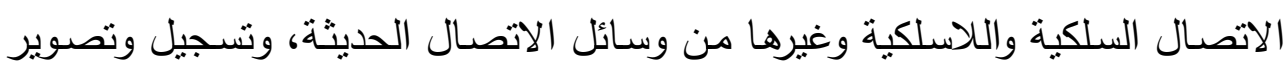

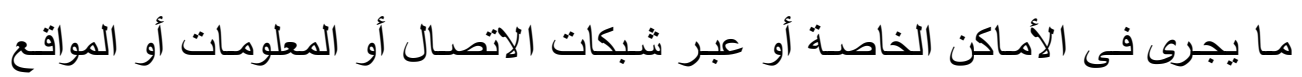

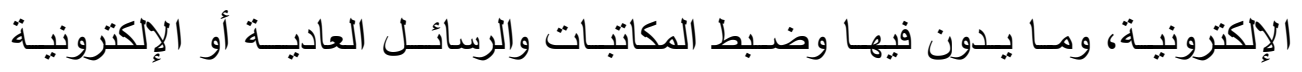
والمطبوعات والطرود والبرقيات بجميع أنواعها. ويجوز تجديد الأمر المشار إليه فى الفقرة الأولى من هذه الماعهادة مدة أولى مداد مددا أخرى ممانلة". - فائدة المراقبة فى إظهار الحقيقة: ثقرر التشريعات أن "ضابط فائدة المراقبة

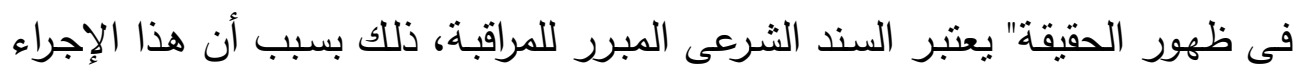

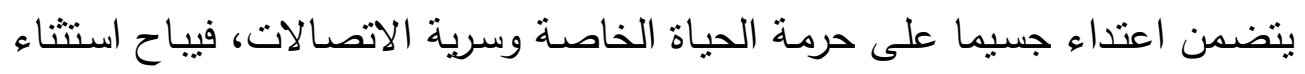

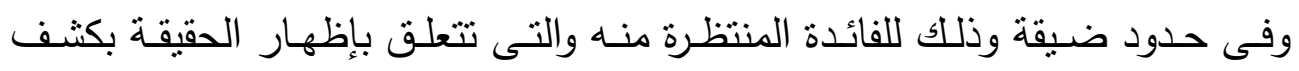
غموض الجريمـة وضبط الجناة. ويترك لقاضى التحقيق أو للقاضى الجزئى تقدير

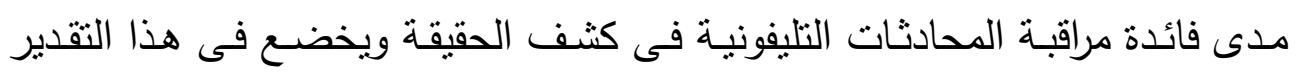
لرقابة قضاء الموضوع (·•). 


\section{المراجع والهواهش}

1- عبد الفتاح بيومى حجازى، الإثبات الجنائى فى جرائم الكمبيوتز والإنترنت، دار الكتب القانونية،

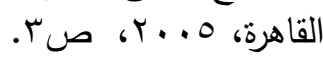

r- نبيلة هبة هرول، الجوانب الإجرائية لجرائم الإنترنت فى مرحلة جمع الاستدلالات - دراسة

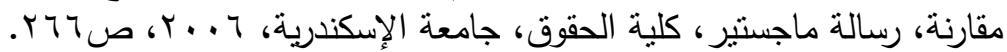

r- هلالى عبد اللاه أحمد، اتفاقية بودابست لمكافحة جرائم المعلومات، دار النهضة العربية،

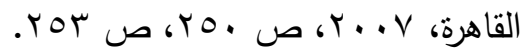

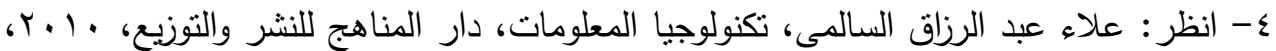

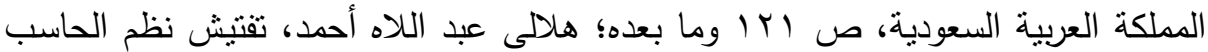

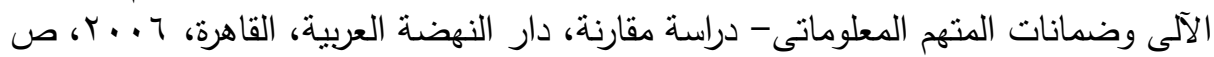

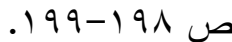

0 - هناك خدمات مصرفية إلكترونية عديدة قد أدخلتها المصارف وأهمها: خدمات التوكيل الإكترونى، خدمة الصراف الآلى والتى تستخدم فى السحب والإلى الإيداع النقدى وتحويل الأموال

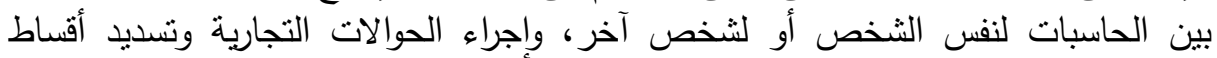

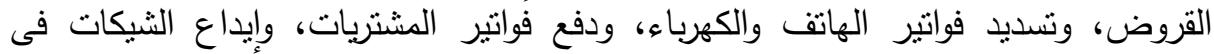

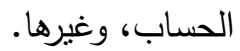

צ- المؤتمر الدولى الخامس عشر للجمعية الدولية لقانون العقوبات، والذى عقد فى ريو دى

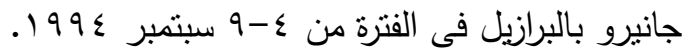

7 - L'Article 17-1/3du Loi no 2003-239 du 18 mars 2003 pour la sécurité intérieure en Frqnce dispose que:(Les données auxquelles il aura été permis d'accéder dans les conditions prévues par le présent article pouvent ètre copiées sur tout support Les supports de stockage informatique peuvent ètre saisis et placés sous scellés dans les conditions prévues par le présnt code.

1 - هلالى عبد اللاه أحمد، تفتيش نظم الحاسب الآلى، مرجع سابق، ص 199.

9- هشام محمد فريد رستم، الجوانب الإجرائية للجرائم المعلوماتية، مكتبة الآلات الحديثة، أسيوط، هردا،

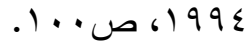

• 1 هلالى عبد اللاه أحمد، مرجع سابق، ص ا. 1. ب.

Ir. 
11 - Sagros "Pierre" et Masse "Michel": le "droit pénal et informatique", études du 15 Nov 1990 - Publication d'institut de sciences Criminelle, faculté de droit poitierséd. cujas tom. IV .p.25.

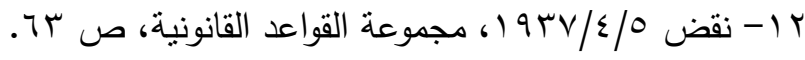

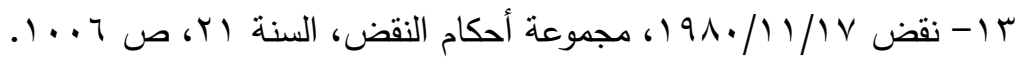

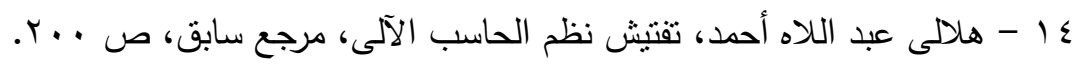

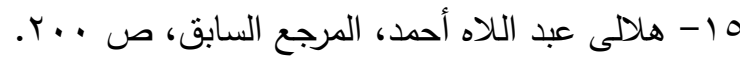

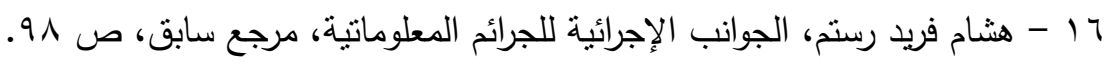

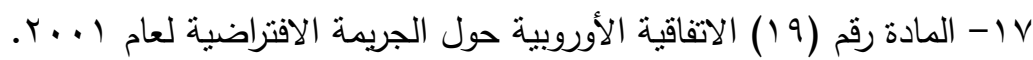

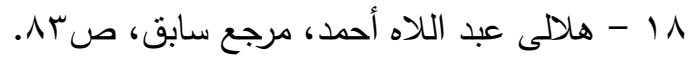

19- CROZE (H): "L' Apport du Droit Pénal a la théorié générale du droit de l'informatique ".J. c. p. 1988, 1.333. No. 16.

20- Moehrenschlager (manfred): "Computer crimes and other crimes against information technology in Germany. National Report." R. I. D. P. 1993. p. 351.

21- Roger Merle - Andre vitu: Traité de droit criminel. Proc-édure pénal. Cujas, Paris, (5 édition), 2001. p. 1802.

22- Meunier (c): La loi du 28 November 2000 relative a la criminalite informatique Crime. Rev. dr. pen. 2002, p. 674.

$$
\begin{aligned}
& \text { r r - تتص المادة (70) من قانون الإجراءات الجنائية المصرى على أنه "توضع الأثياء والأوراق }
\end{aligned}
$$

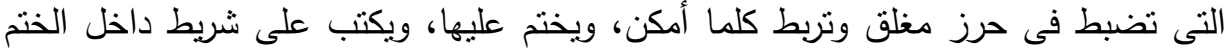

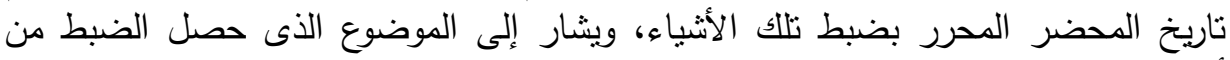

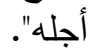

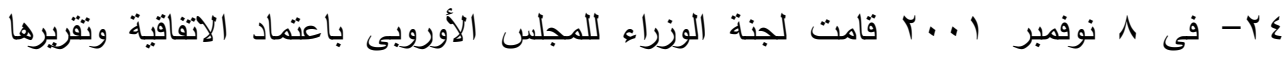

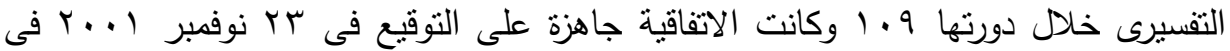

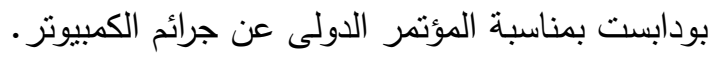

$$
\begin{aligned}
& \text { هץ- للاطلاع على النص الكامل لاتفاقية بودابست، يرجى مراجعة الموقع الخاص بالمجلس } \\
& \text { http://www.convention.coe.int/treaty/EN/treaties/htm1/185.htm. } \\
& \text { الأوروبى: }
\end{aligned}
$$


- وقد جاء فى ديباجة اتفاقية المجلس الأوروبى حول الإجرام السيبيرى بيانُ لمخاطر انتشار شبكة

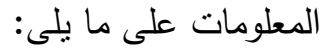

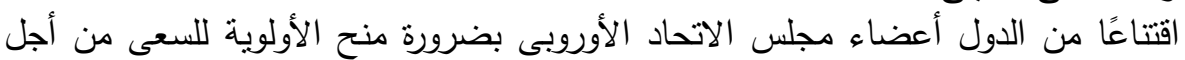

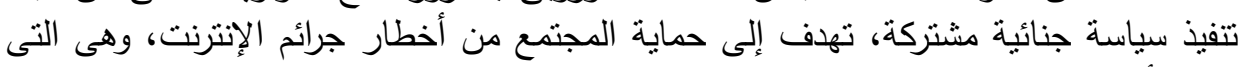

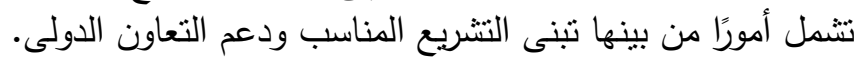

- وادراكا لعمق التغيرات التى أحدثها التحول إلى الإكترونية وارتباط شبكات الكمبيوتز مع بعضها ألبعض مع استمرار عولمتها.

- وانشغالًا بمخاطر احتمال استخدام شبكات الكمبيوتز والمعلومات الإلكترونية أيضا فى ارتكاب جرائم جنائية.

جr- الوثيقة التفسيرية لاتفاقية بودابست، الذى أعدته لجنة الوزراء للمجلس الأوروبى خلال دورتها،

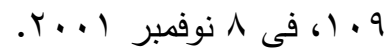

L rV

28- Agent may direct providers to preserve existing record pending the issuance of compulsory legal process. Such requests have no however, prospective effect.

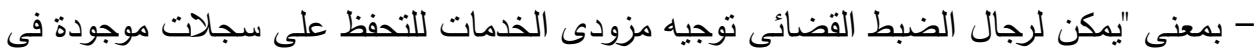

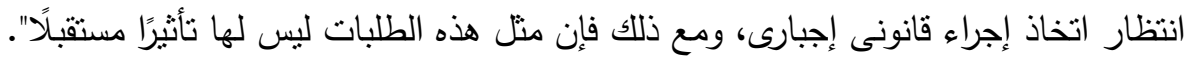

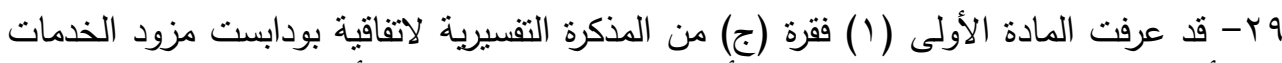

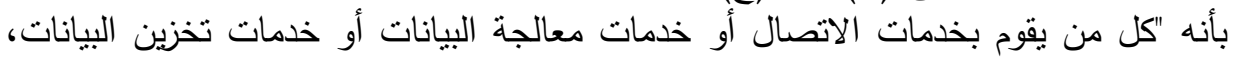

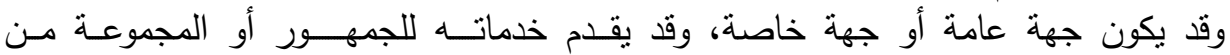

المستخدميـن الذيـن يشكلون مجموعة مغلقة (كثركة مثنلا).

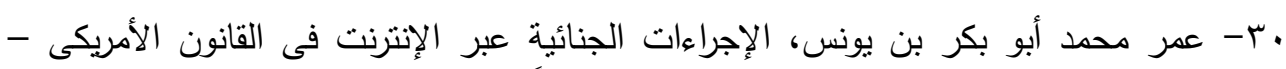

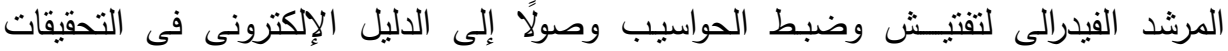

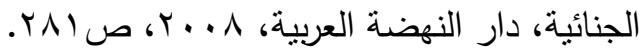

31 - Art. L. 32-3-1 alinéa 1 du code des postes et télécommunications dispose que: "Les opérateurs de télécommunications, et notamment ceux mentionnés á l'aricle 43-7 de la loi nº6-1067 du 30 septembre 1986 précitée, sont tenus d'effacer ou de rendre anonyme toute donnée relative á une communication dés que celle-ci est achevée, sous réserve des dispositions des II, III et IV". 
r ب- ينبغى التنبيه أن المشرع الفرنسى مد التزام مزودى الخدمات فى الحفاظ على البيانات المتعلقة

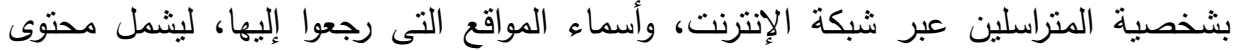

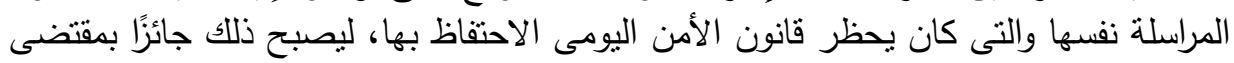

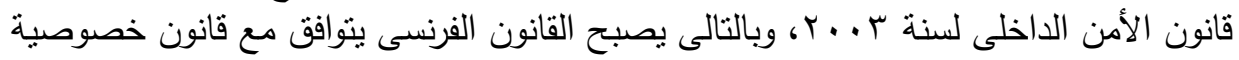
الاتصالات الإكترونية الأمريكى (ECPA).

33 - Art. L. 23-3-1 alinéa 2 du code des postes et télécommunications dispose que:

"Pour les besoins de la recherche, de la constatation et de la poursuite des infractions pénales, et dans le seul but de permettre, en tant que de besoin, la mise disposition de l'autorité judiciaire d'informations, il peut être différé pour une durée maximale d'un an aux opérations tendant á effacer ou á rendre anonymes certaines catégories de données techniques".

ء ז- هناك فرق بين التحفظ على البيانات والاحتفاظ أو أرشفة البيانات ويقصد بالأول حفظ بيانات

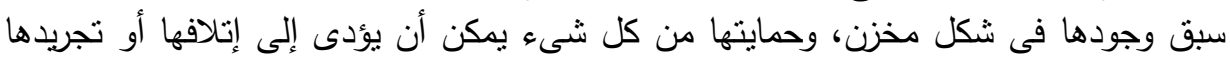

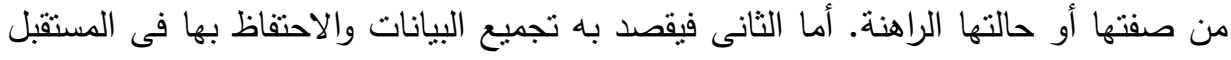

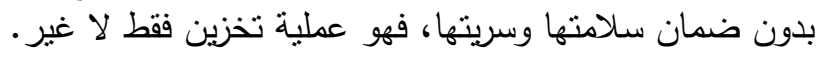

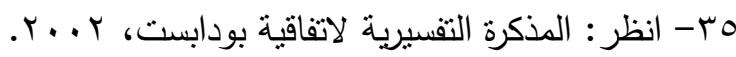

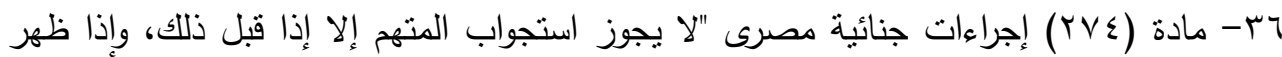

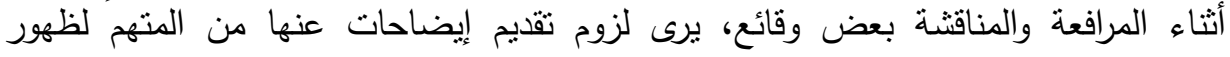

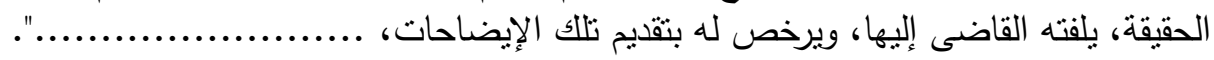

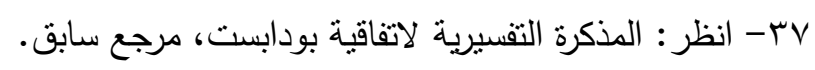

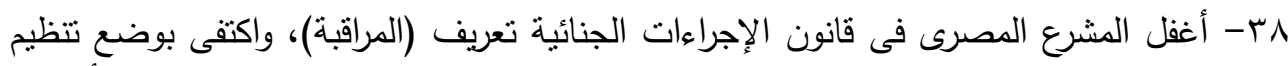

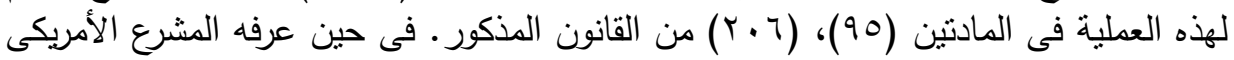

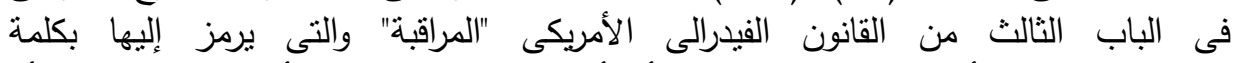

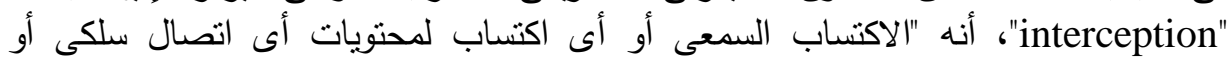

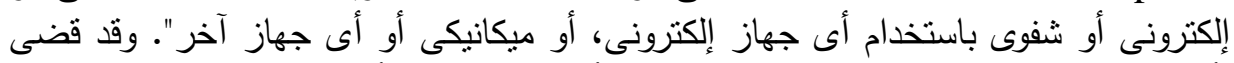

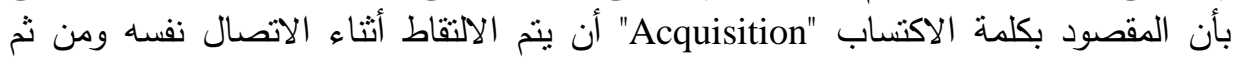

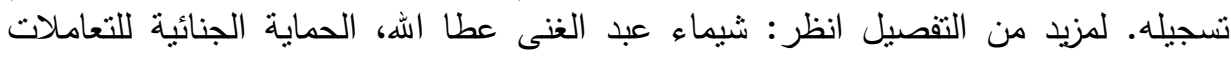

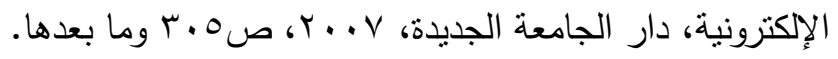




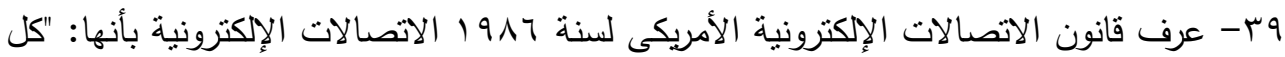

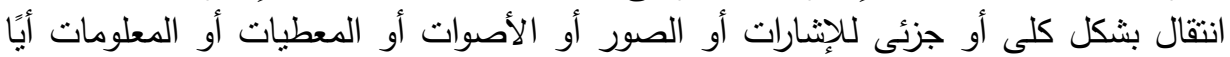

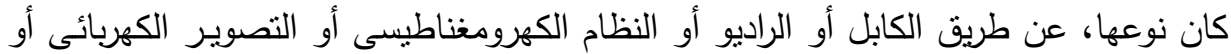

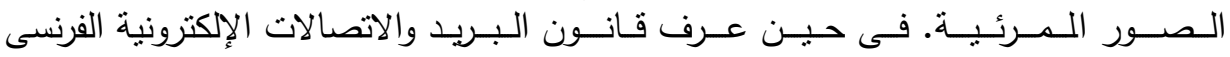
Code des postes et des communication Décret n $80-567$, eléctroniques (Journal

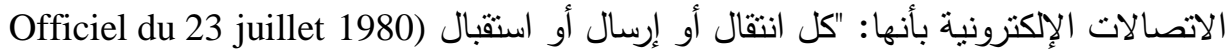
لإثارات أو علامات أو كتابة أو صور أو أصوات أو أرسات عن طريق النظام الكهرومغناطيسى.

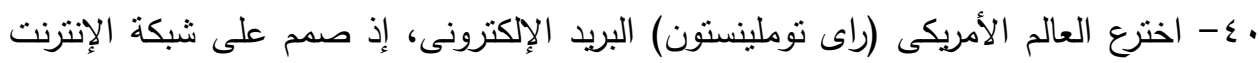

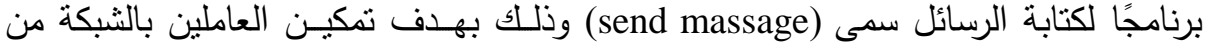

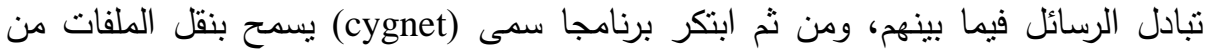

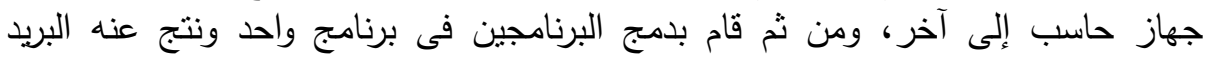

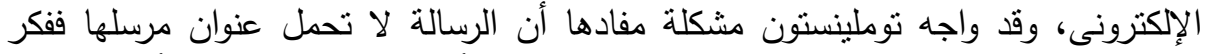

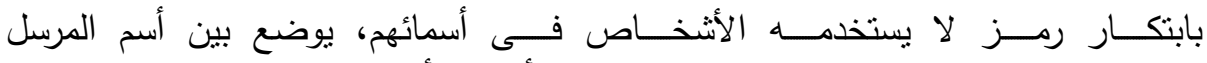

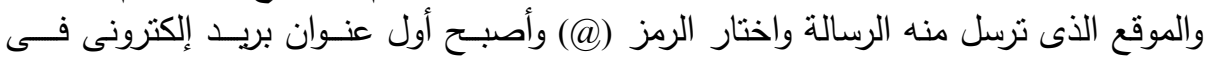

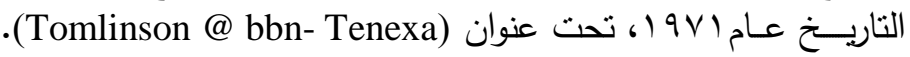

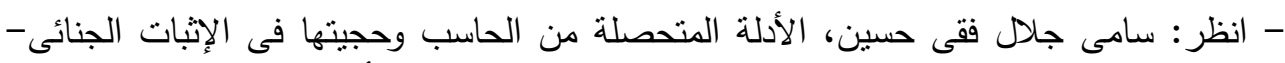

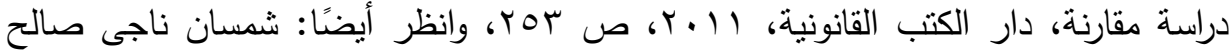

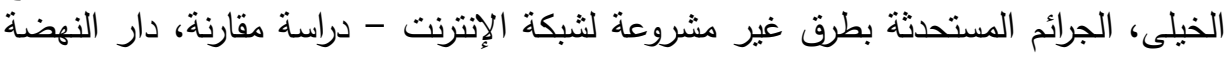

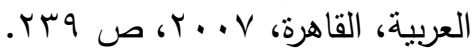

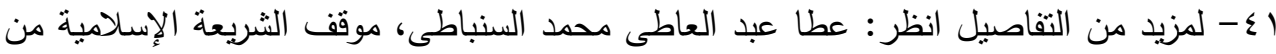

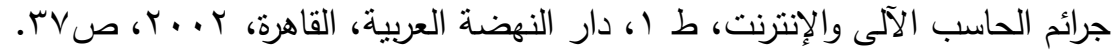

r - إيهاب عبد المطلب، الموسوعة الجنائية الحديثة فى شرح قانون الإجراءات الجنائية، المركز

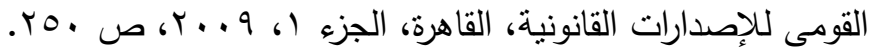

43 - crim.4 sept. 1991: Bull.crim.no 132.

44 - United States v. Smith, 155 F. 3d 1051, 1058-59 (9thCir. 1998).

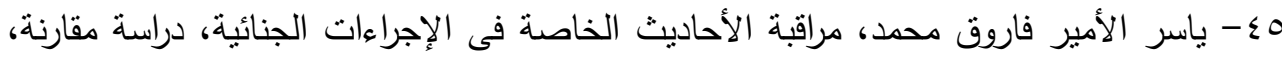

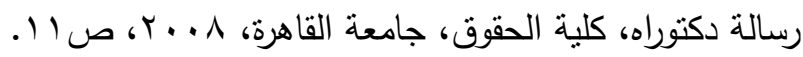

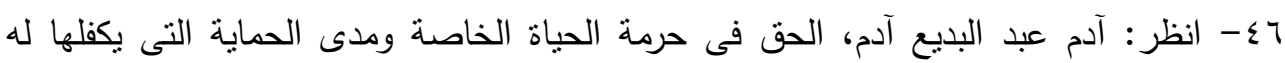

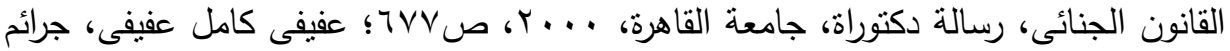


الكمبيوتر وحقوق المؤلف والمصنفات الفنبة، ودور الثرطة والقانون، دراسة مقارنة، منشأة المعارف، الإسكندرية، بدون تاريخ، ص ع ع ب وما بعدها.

V乏 - أحمد حسام طه تمام، الحماية الجنائية لتكنولوجيا الاتصالات، دراسة مقارنة، دار النهضة

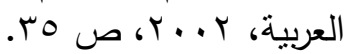

48- Renault - Brahinskg (Corinne), l'essentiel de la procédure pénale, 5e éd., gualino étiteur, E J A, coll. "les carres" paris, 2004, p. 330.

9؟- لمزيد من التفاصيل حول المعايير التى تعتد بها التشريعات الجنائية لتحديد مفهوم الحديث

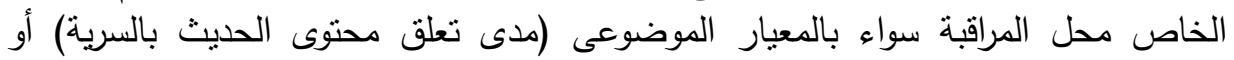

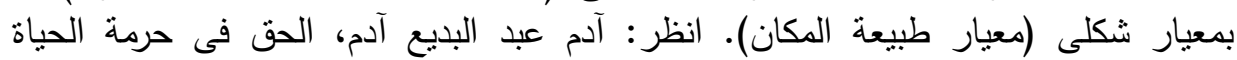

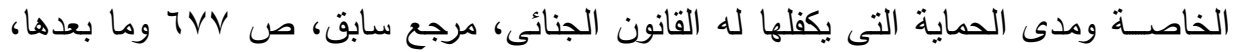

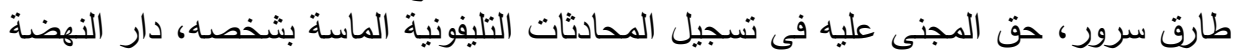

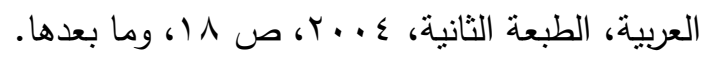

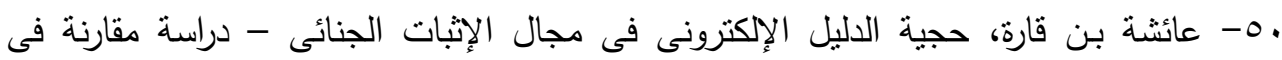

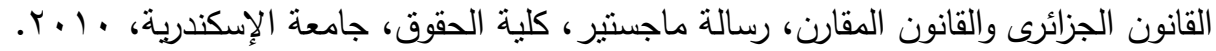

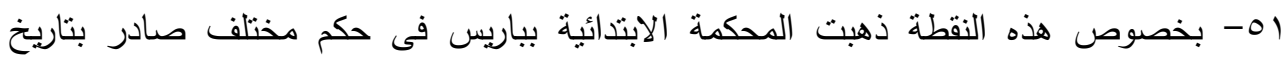

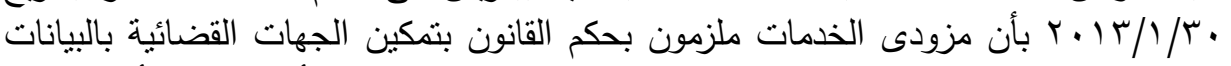

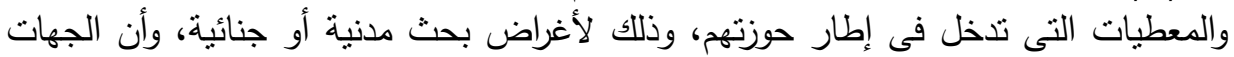
المذكورة لا تتحمل أية مسئولية قانونية مادام القانون الفرنسى والقوانين الأوروبية تجيز لها ذلائه للك.

$$
\text { ror }
$$

ro- عائشة بـن قارة، حجية الاليل الإككترونى فى الإثبات فـى المجـال الجنائى، مرجع سابق، ص ص IVT

54- Article (100) de (C.P.P) Francais dispose que: "En matiére criminelle et en matiére corr-ectionnelle, si la peine encourue est égale ou supérieure á deux ans d'emprisonnement, le juge d'instruction peut, lorsque les nécessités de l'information l'exigent, prescrire l'interception, l'enregistrement et la transcription de correspon-dances émises par la voie des télécommunications".

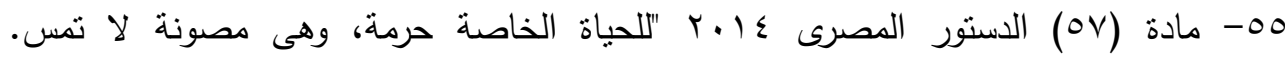

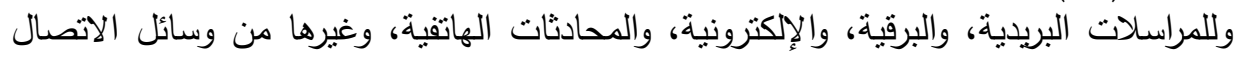

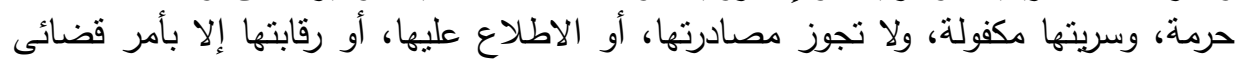
مسبب، ولمدة محددة، وفى الأحوال التى يبينها القانون. كما تلنزم الدولة بحماية حق التهابة المواطنين 
فى استخدام وسائل الاتصال العامة بجميع أثنكالها، ولا يجوز تعطيلها أو وققها أو حرمان المواطنين منها، بشكل تعسفى، وينظم القانون ذلك".

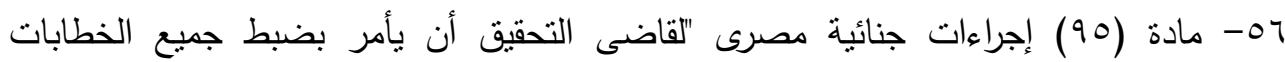

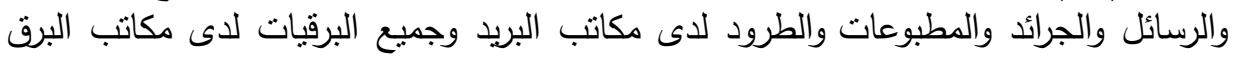

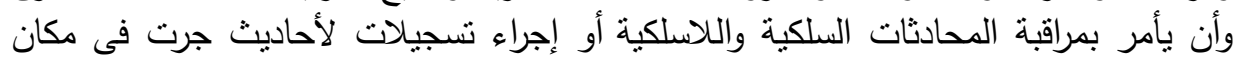

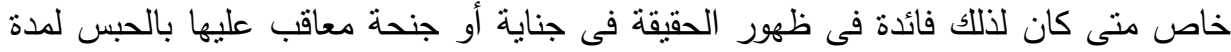

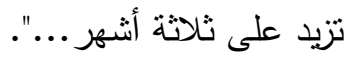

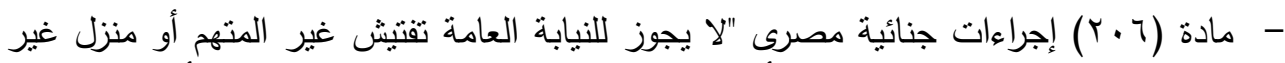

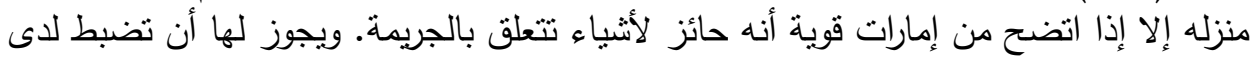

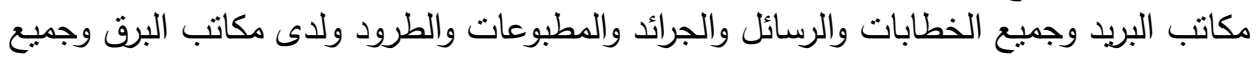

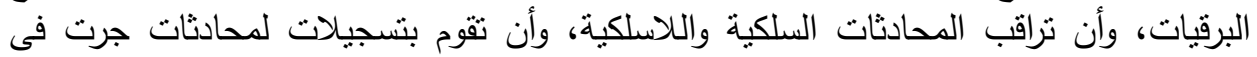

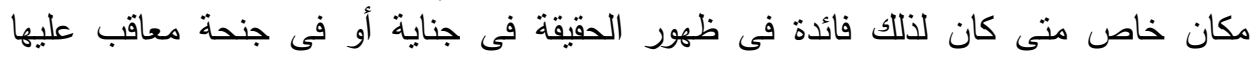
بالحبس لمدة تزيد على ثلاثة أثنهر ـ ويشترط لاتخاذ أى إجراء من الإجراءات السات السابقة الحصول

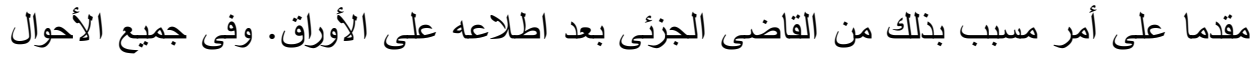

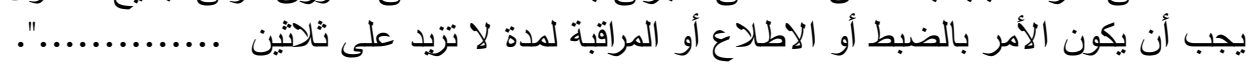

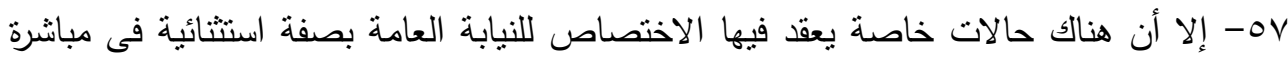

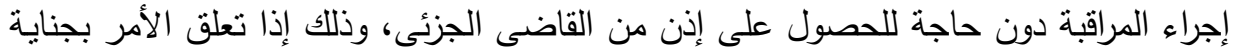

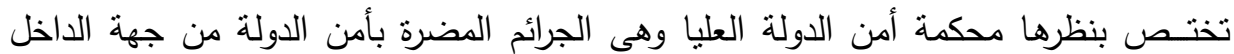

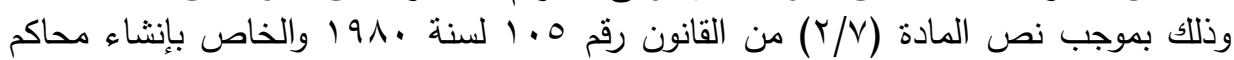

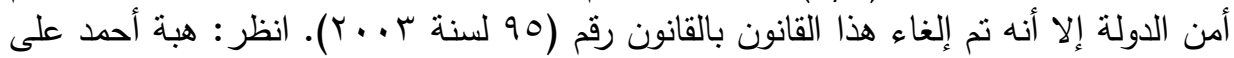

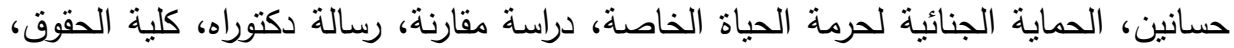

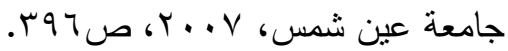

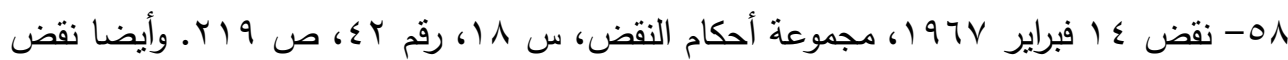

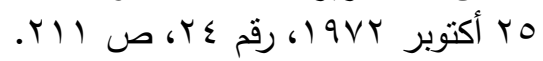

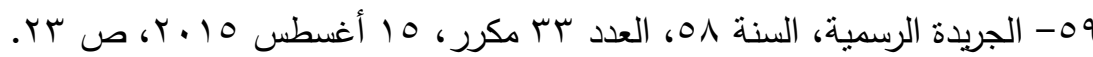

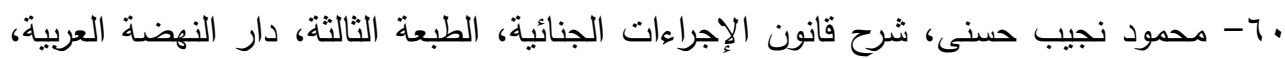

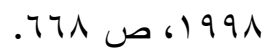




\section{EVIDENCE SEIZURE IN ELECTRONIC CRIMES: TRADITIONAL AND MODERN PROCEDURES}

\section{Hend Nageb}

The study focuses on traditional and modern procedures of evidence seizure in electronic crimes. It sheds light on the extreme importance and difficulties faced by law enforcement and investigation authorities, relative to said procedures and crimes., Whereas computer system has material and non-matrial contents, such as data and information, the seizure is not restricted to material contants only; but also involves the non-matrial contents and e-mails as well. 
IrN 